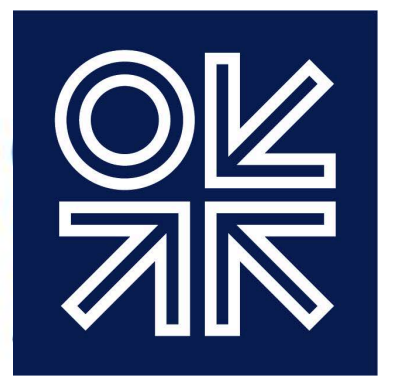

THE OXFORD INSTITUTE FOR ENERGY STUDIES

December 2019

\title{
China and IMO 2020
}

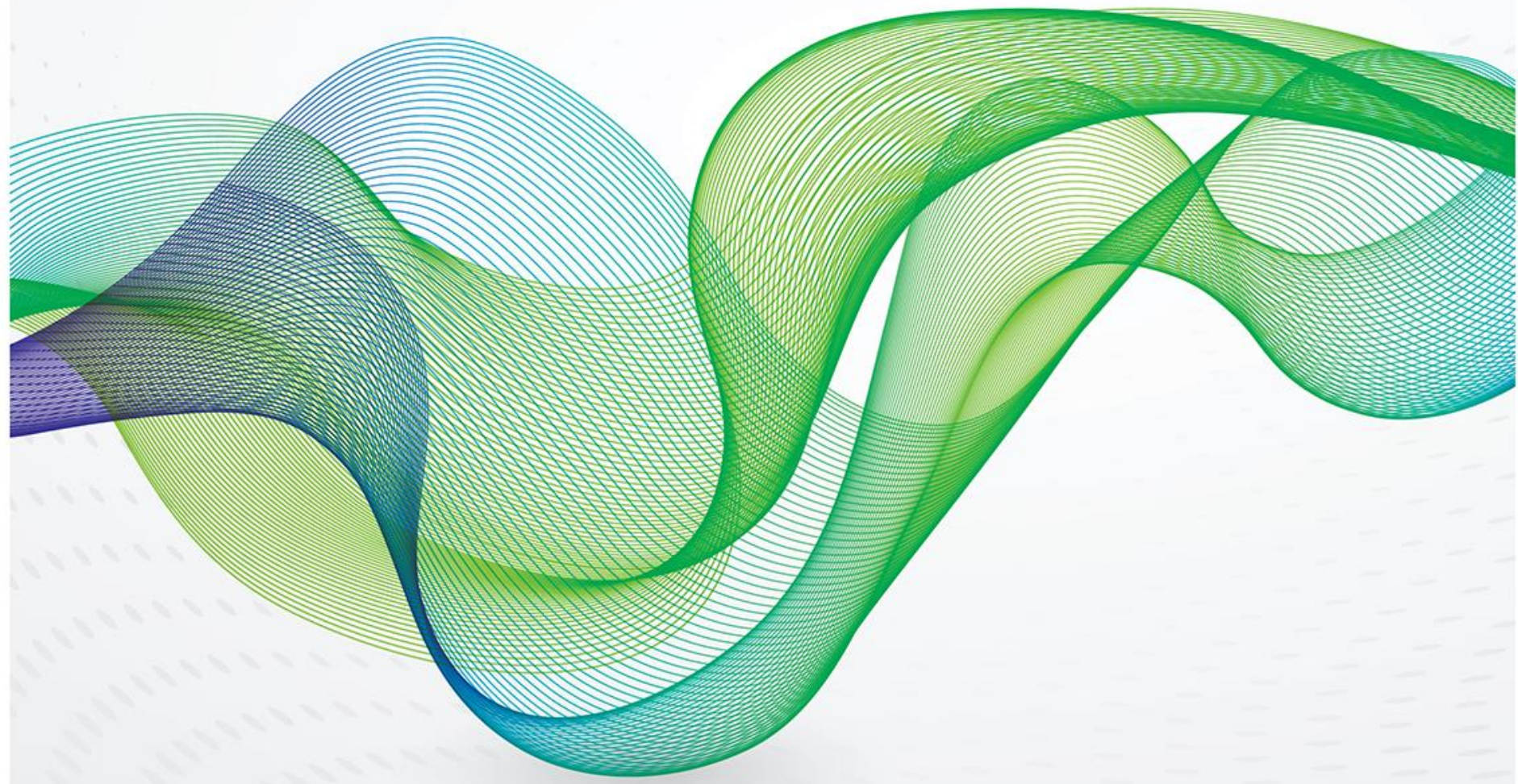


The contents of this paper are the author's sole responsibility. They do not necessarily represent the views of the Oxford Institute for Energy Studies or any of its members.

Copyright (C) 2019

Oxford Institute for Energy Studies

(Registered Charity, No. 286084)

This publication may be reproduced in part for educational or non-profit purposes without special permission from the copyright holder, provided acknowledgment of the source is made. No use of this publication may be made for resale or for any other commercial purpose whatsoever without prior permission in writing from the Oxford Institute for Energy Studies.

ISBN : 978-1-78467-154-9

DOI: https://doi.org/10.26889/9781784671549 


\section{Contents}

Contents 3

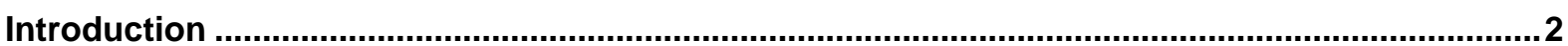

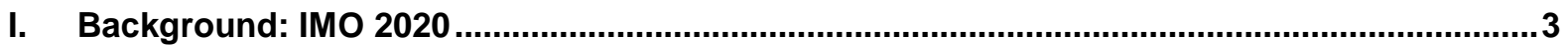

II. China: Tough government policies to tackle shipping emissions... ....................................5

III. ...but a relatively muted response from refiners ................................................................... 7

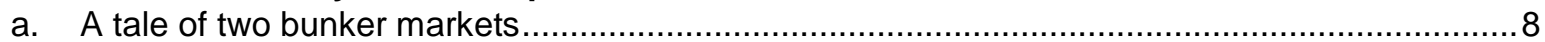

b. The domestic market is dominated by blenders . . . .

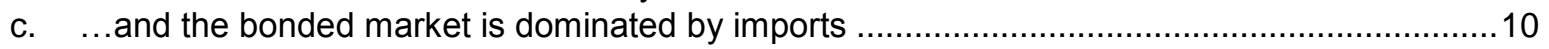

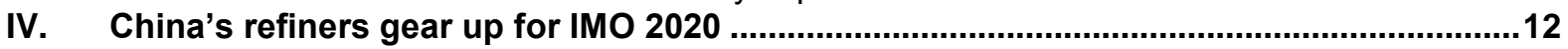

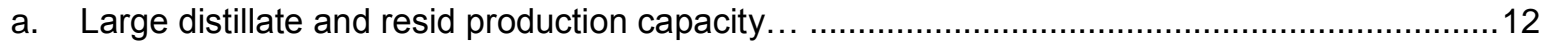

b. ...but China's refiners are focusing on VLSFO ......................................................... 14

V. New tax scheme and FTZs support VLSFO production and exports .......................................18

VI. LNG bunkering - the next frontier ....................................................................................19

Conclusion .........................................................................................................................................22

\section{Figures and Tables}

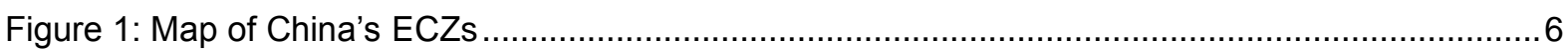

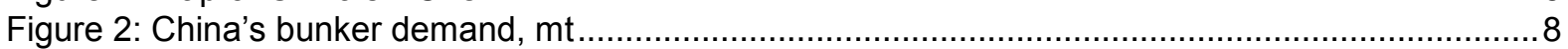

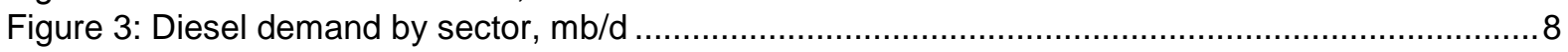

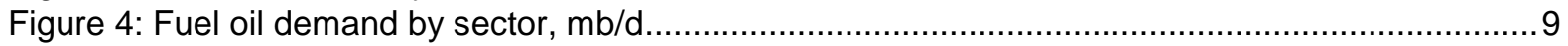

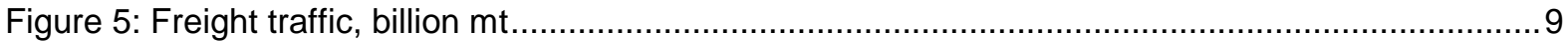

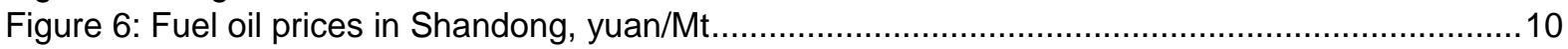

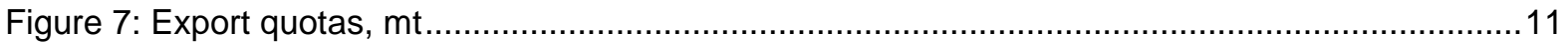

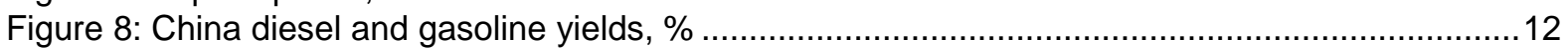

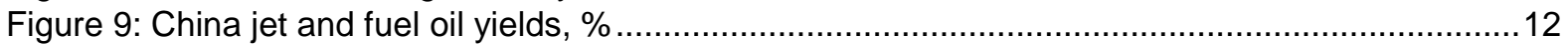

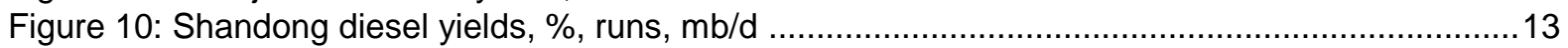

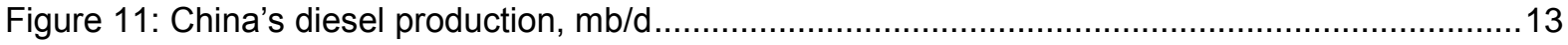

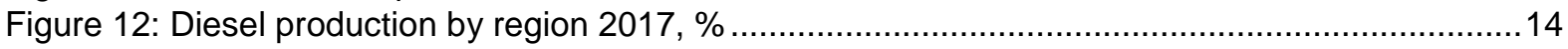

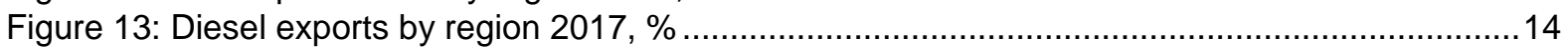

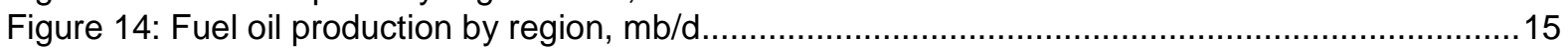

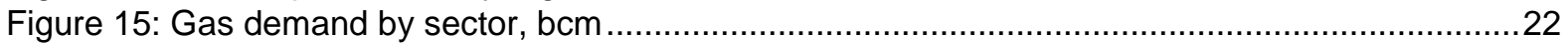

Table 1: Sinopec and PetroChina refineries producing IMO-compliant VLSFO ..............................16

Table 2: Subsidies for inland LNG ships, \$ millions .......................................................... 19 


\section{Introduction}

Shippers and refiners have been actively preparing for the International Maritime Organization (IMO) transition to very low sulphur fuel oil (VLSFO), engaging in a lively debate on how it would play out and, since the second half of 2019, making active preparations for it. Chinese refiners, however, seem to have been less preoccupied with it than their Western peers. This may seem surprising given that China holds the world's second largest refining capacity behind the US, is home to six of the ten largest container ports globally, and is an early adopter of tighter shipping fuel emission standards domestically.

One key reason is that China's domestic bunker market is small relative to its refining capacity and to other Asian hubs. At 20 million tonnes (mt), China's sales were equivalent to just 40 per cent of the bunkering volumes sold at the port of Singapore alone (about $50 \mathrm{mt}$ ) in 2018. Of this $20 \mathrm{mt}$, domestic bunkering accounted for 6-7 mt and bonded ${ }^{1}$ bunkering represented an additional $13 \mathrm{mt}$. Yet the domestic tax system, which adds both consumer and value-added tax (VAT) to bunker fuels, even for bonded sales, ${ }^{2}$ makes refinery-based bunker fuels uncompetitive. It leaves blenders, who generally import about 90 per cent of their raw material, mainly from Singapore and Malaysia, to dominate supplies.

However, this may be changing. IMO 2020 presents an opportunity for refiners, and the government's efforts to promote China as a bunkering hub on a par with Singapore is heralding a change. China's state-owned refiners started gearing up to produce VLSFO in 2019, having announced plans to produce close to $20 \mathrm{mt}$ of VLSFO in 2020. Expectations that the government will offer tax rebates on VLSFO exports have boosted refiners' enthusiasm for the fuel, while the Free Trade Zone (FTZ) at Zhoushan port, where the government has relaxed restrictions on imports of marine fuels and blendstocks, is also supporting the nascent market.

Eventually, China will be able to supply the full volume of compliant bunkers in its ports without imports. And even though refiners can also produce compliant marine gasoil (MGO), the high consumption tax levied on it and restrictive export quotas suggest it will struggle to compete with VLSFO. At the same time, higher VLSFO output will require some refiners to shift their crude slate to sweeter crudes, which are currently commanding a premium, and squeeze production of clean products. With excess refining capacity and weakening gasoline demand growth, these adjustments are unlikely to be a problem for China's refining system and over time Chinese refiners are likely to emerge as growing suppliers of low-sulphur bunker fuels.

Yet even though the immediate focus is on VLSFO, the government's medium- and long-term plans emphasize liquefied natural gas (LNG) in shipping. Use of LNG for bunkering in China's inland waterways has been part of government plans to switch to low-sulphur fuels since 2013, but the lack of LNG vessels as well as refuelling and bunkering infrastructure has limited its growth, with shipping estimated to account for only 1.5 billion cubic metres (bcm) of China's $280 \mathrm{bcm}$ of natural gas demand in 2018. In late 2018 the government announced a stronger policy focus on developing LNG in shipping through to 2025, and therefore the state-owned oil and gas companies, as well as shippers, are increasingly setting their sights on LNG in shipping for both domestic and international bunkering. These developments in China's bunkering market are set to weigh on diesel use, benefitting fuel oil in the near term and LNG, at the margins, from 2025. At the same time, the stateowned oil and gas majors are set to recapture market share from blenders as they develop supplies of both VLSFO and LNG.

\footnotetext{
I would like to thank Adi Imsirovic, Chris Le Fevre, Jack Sharples and Bassam Fattouh for their additions, edits and comments which have greatly enriched my analysis. Any errors or omissions, however, remain my own.

1 Provision of fuel sold tax-free to ships travelling between countries across international waters.

2 China imposes a consumption tax of CNY 1,218 (about \$175) per tonne plus 13 per cent VAT (over \$70) for LSFO.
} 
In this paper, we analyse these developments and their implications for China's oil and gas majors. The first section provides a brief overview of the IMO 2020 regulations and their global impact. The second part reviews the Chinese government's policies to tackle maritime pollution, before assessing, in the third section, how the prohibitive domestic tax regime and restrictive export quotas have made Chinese refiners relatively passive participants in both China's domestic bunkering market and the global IMO transition. The fourth section takes stock of China's refining capacity and ability to produce IMO-compliant fuels, both MGO and VLSFO. In the fifth section, we analyse the upcoming changes to the tax system, which are set to support refiners' production and export of VLSFO, as well as developments in the Zhoushan FTZ, which is attracting China's blenders from the domestic market and relocating competition with the refiners offshore. Finally, even though VLSFO is emerging as the short-term fuel of choice for Chinese refiners, Beijing's emphasis on natural gas in shipping through to 2025 suggests that both domestic shippers as well as the gas majors will increasingly focus on developing the nascent LNG bunkering market, which we review in the sixth and final section.

\section{Background: IMO 2020}

IMO regulations to reduce emissions of sulphur oxides (SOx) from ships first came into force in 2005, under Annex VI of the International Convention for the Prevention of Pollution from Ships (known as the MARPOL Convention). Since then, the limits on SOx have been progressively tightened and from 1 January 2020 the limit for sulphur content of exhaust emissions from ships operating outside designated emission control areas will be reduced to 0.5 per cent $\mathrm{m} / \mathrm{m}$ (mass by mass), from 3.5 per cent currently.

On the basis of current technology, shippers have three main options to meet the new requirements:

- They can run on LNG.

- They can switch from high-sulphur fuel oil (HSFO), the main bunkering fuel currently in use, to a lower-sulphur fuel such as MGO or a new type of residual fuel known as VLSFO.

- Finally, they can continue to use HSFO and process air emissions through an exhaust gas cleaning system more commonly called 'scrubbers' which must be retrofitted on board the ship, along with dedicated tanks to hold and treat resulting wastewater from the process. ${ }^{3}$

For shippers, each option has its costs and benefits, but before the new regulations kick in, markets are still struggling to price in the cost of each option. Investing in an LNG engine makes sense for shippers from a long-term perspective, especially if the global IMO cap is later extended to cover nitrogen oxides $(\mathrm{NOx})^{4}$ or greenhouse gases more widely (in addition to $\mathrm{SOx}$ emissions, which are the main focus currently), as LNG used in bunkering is low in both SOx and NOx emissions. Current economics are certainly encouraging as the LNG fuel equivalent is at least 30 per cent cheaper than fuel oil. ${ }^{5}$ Over time, however, LNG will remain appealing only as long as natural gas prices stay

\footnotetext{
3 Adi Imsirovic and Ben Pryor, 'IMO 2020 and the Brent-Dubai Spread', Oxford Energy Comment, September 2018, https://www.oxfordenergy.org/wpcms/wp-content/uploads/2018/09/IMO-2020-and-the-Brent\%E2\%80\%93DubaiSpread.pdf?v=79cba1185463; Antoine Halff, Lara Younes andJack Sharples, "LNG Supply Chains and the Development of LNG as a Shipping Fuel in Northern Europe", OIES Paper, NG 140, January 2019, https://www.oxfordenergy.org/wpcms/wpcontent/uploads/2019/01/LNG-supply-chains-and-the-development-of-LNG-as-a-shipping-Fuel-in-Northern-Europe-NG140.pdf?v=79cba1185463; Antoine Halff, Lara Younes, Tim Beorsma, 'The likely implications of the new IMO standards on the shipping industry', Energy Policy, Vol. 126 (2019), pp. 277-286; 'IMO 2020: What every shipper needs to know', HISIHS Whitepaper, March 2019, https://www.joc.com/sites/default/files/u45421/Whitepapers/GeminiSeaburyWP 24pages.pdf. 4 NOx is capped globally, but at a level that effectively allows a business as usual model. A more stringent cap applies to vessels built from 2016 onwards in the North American ECA and will apply to newbuild vessels in Northern Europe from 2021. But it is far from clear if and when these more stringent limits may be applied globally. See Jack Sharples, "LNG Supply Chains and the Development of LNG as a Shipping Fuel in Northern Europe", OIES Paper, NG 140, January 2019 https://www.oxfordenergy.org/publications/Ing-supply-chains-development-Ing-shipping-fuel-northerneurope/?v=79cba1185463, page 5 for more details.

50.5 per cent fuel oil \$554 v \$377 LNG equivalent, Platts Bunkerwire 4/12/19 (9.75 Mmbtu (million British thermal units)).
} 
relatively low ${ }^{6}$ and would entail significant losses if natural gas prices rallied and oil-based fuel differentials narrowed. Meanwhile, the LNG and scrubber options both entail multimillion-dollar upfront capital expenditures, including the capital cost of new processing units and storage tanks (for LNG or wastewater), in addition to the one-off loss of revenue from laying up ships in dry dock for weeks to be retrofitted, and the permanent cost of losing deck space and loading capacity to the new equipment.

In the short term then, switching to low-sulphur fuel will spare shippers the up-front cost of a scrubber or LNG engine, but it would be a loss-making proposition if VLSFO premiums were to rise. Scrubber costs are likely to depend on technological developments, so for shippers the decision depends on both scrubber costs, potential restrictions on the disposal of wash water, and the price of HSFO, with HSFO prices now beginning to plummet as the transition approaches. ${ }^{7}$

Refiners have also faced considerable uncertainty, struggling to assess the redistribution of demand, but fundamentally, their options include:

- Switching crude slates to prioritize low-sulphur feedstocks;

- Altering refinery configuration to maximize gasoil production at the expense of fuel oil and naphtha-if they assume the response to IMO 2020 will be an uptick in MGO demand at the expense of fuel oil.

- Investing in cokers and hydrocrackers to crack the heavier fuel oil molecules into lighter components.

- Blending HSFO with alternative low-sulphur fuels, to produce a product that is compliant.

Refiners' choices will be informed not only by the availability of low-sulphur feedstock (and more precisely, crudes with low-sulphur residue cuts) and their refining upgrade plans, but also storage availability for clean fuels. Also, while refiners decide which low-sulphur fuel to prioritize, they will also need to find an alternative home for some existing HSFO. Wide inter-product spreads and higher VLSFO-HSFO differentials should gradually incentivize refineries to reduce HSFO output, but that, in turn, would make its availability a problem for the ships with scrubbers. Yet scrubber uptake and refinery upgrades will, in time, narrow these product spreads suggesting that for both shippers and refiners, forecasting bunker fuel supply and demand remains a moveable feast. ${ }^{8}$

Consensus has held until recently that the industry will initially rely on MGO, given that it is already familiar to many shippers and the quality will be consistent in ports around the world. However, at the time of writing, VLSFO demand seems set to eclipse MGO use ${ }^{9}$, at least in the first few months of the IMO transition in 2020. This is because shippers simply opt for a cheaper compliant fuel. However, this has resulted in the premium shrinking substantially, making MGO only marginally more expensive. With up to $10 \mathrm{mt}$ of IMO-compliant marine fuel currently stored in floating storage and landed terminals in and around Singapore and Malaysia, the industry seems well prepared for now. The emerging question is increasingly, will there be enough VLSFO beyond Q1 20 and if not, when will distillate markets begin to price in the response? Fundamentally, however, MGO and VLSFO both trade at a premium to HSFO, so shippers have limited incentive to use these higher-cost fuels until required. ${ }^{10}$

\footnotetext{
6 M. Acciaro, 'Real option analysis for environmental compliance: LNG and emission control areas', Transp. Res. Part D: Transp. Environ., Vol. 28 (2014), pp. 41-50.

7 In theory, shippers installing scrubbers could hedge this investment by hedging in the derivatives market. However, with the IMO changes, liquidity in the HSFO paper market has dried up, while LSFO derivatives have not taken off yet. In the meantime, the quality of the available assessments may be an issue.

8 Adi Imsirovic and Ben Pryor, 'IMO 2020 and the Brent-Dubai Spread', Oxford Energy Comment, September 2018, https://www.oxfordenergy.org/wpcms/wp-content/uploads/2018/09/IMO-2020-and-the-Brent\%E2\%80\%93DubaiSpread.pdf?v=79cba1185463.

9 In addition, because MGO is lighter, it does not have the same lubricating properties as VLSFO. The latter is closer in consistency to the high sulphur fuel oil hat is currently being used.

10 At the time of writing, the VLSFO-HSFO spread in Singapore is $\$ 233 / \mathrm{Mt}$. A laden VLCC (very large crude carrier) can save up to $\$ 0.5$ million on a typical Persian Gulf to China (TS3c) voyage.
} 


\section{China: Tough government policies to tackle shipping emissions...}

With severe air pollution episodes occurring increasingly in China in the early 2000s, the Chinese government began adopting tougher ambient air quality standards and implementing a series of measures to improve air quality. Most of these new policies targeted road transport and emissions from freight trucks, with port cities and provinces only gradually focusing on emissions from ships and port activities. Hong Kong was the first to strictly enforce the use of low-sulphur fuel (500 parts per million (ppm), or 0.5 per cent sulphur content) by local vessels in 2014 , followed by Shenzhen, which announced a comprehensive list of measures for cleaning up ships, trucks, and port equipment. Other port cities and regions, including Shanghai, Qingdao, Guangdong, Jiangsu, and Shandong, followed suit, gradually promoting shore power, electrification of port equipment, and the use of electric or natural gas-powered trucks.

As the urgency to tackle pollution rose, regional governments began responding. For example, the port of Shanghai, one of the world's busiest ports, accounted for 12 per cent of the City of Shanghai's total SOx emissions, 9 per cent of its NOx, and more than 5 per cent of its particulate matter (PM) emissions in 2010. In Shenzhen, shipping was found to contribute about two-thirds of SOx, 14 per cent of $\mathrm{NOx}$, and 6 per cent of PM emissions. Efforts to regulate shipping emissions therefore gained momentum and in April 2015 China's Ministry of Transport (MoT) initiated the national Green Port Programme, which assessed and certified the overall environmental performance of a port and, starting on 1 January 2016, issued tighter standards for PM emissions. The government subsequently designated the MoT to implement regional emission control zones and introduced national-level legislation, the Law on the Prevention and Control of Air Pollution, ${ }^{11}$ to frame and support the MoT's efforts, also introducing specific requirements for ships concerning fuel quality, engine standards, and shore power adoption.

In August 2015, the MoT released a Ship and Port Pollution Prevention Special Action Plan (SPPPSAP 2015-2020),12 which included targets to reduce emissions from 2015 levels by 2020 in the Pearl River Delta (PRD), the Yangtze River Delta (YRD), and the Bohai Rim (Beijing-TianjinHebei, Figure 1). Specifically, the SPPPSAP issued the following targets:

- reduce SOx emissions by 20 per cent

- cut NOx emissions by 65 per cent

- reduce PM emissions by 30 per cent.

The plan also sets a target for 90 per cent of working vessels in these areas, including at container and cruise terminals, to use shore power when berthing by 2020, to encourage ships to turn off their diesel engines while at berth. Finally, the plan actively promotes the use of LNG as a primary marine fuel. The benefit of LNG is that it not only reduces SOx emissions to zero, but also reduces NOx and $\mathrm{CO}_{2}$ emissions, the latter being a part of the IMO 2050 carbon limits (to be firmed up by 2023).

\footnotetext{
11 http://www.gov.cn/ziliao/llfg/2005-08/05/content_20945.htm.

12 'Notice regarding the publication of the Ministry of Transport's ship and port pollution prevention Special Action Plan (20152020)' (Chinese) http://www.gov.cn/gongbao/content/2016/content_5038094.htm, August 2015; 'Provisions of the People's Republic of China on the prevention and control of ship pollution in inland waters (Chinese), http://www.gov.cn/gongbao/content/2016/content_5059093.htm.
} 

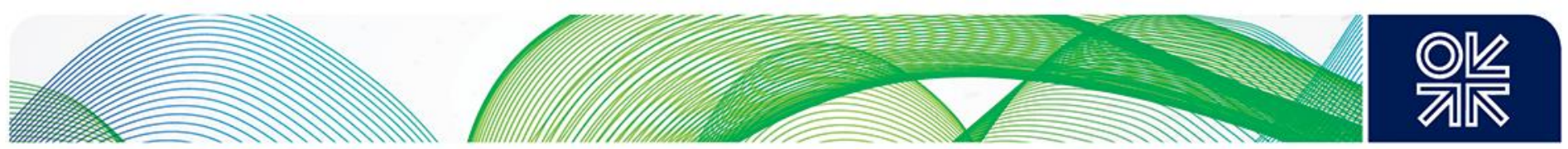

Figure 1: Map of China's ECZs

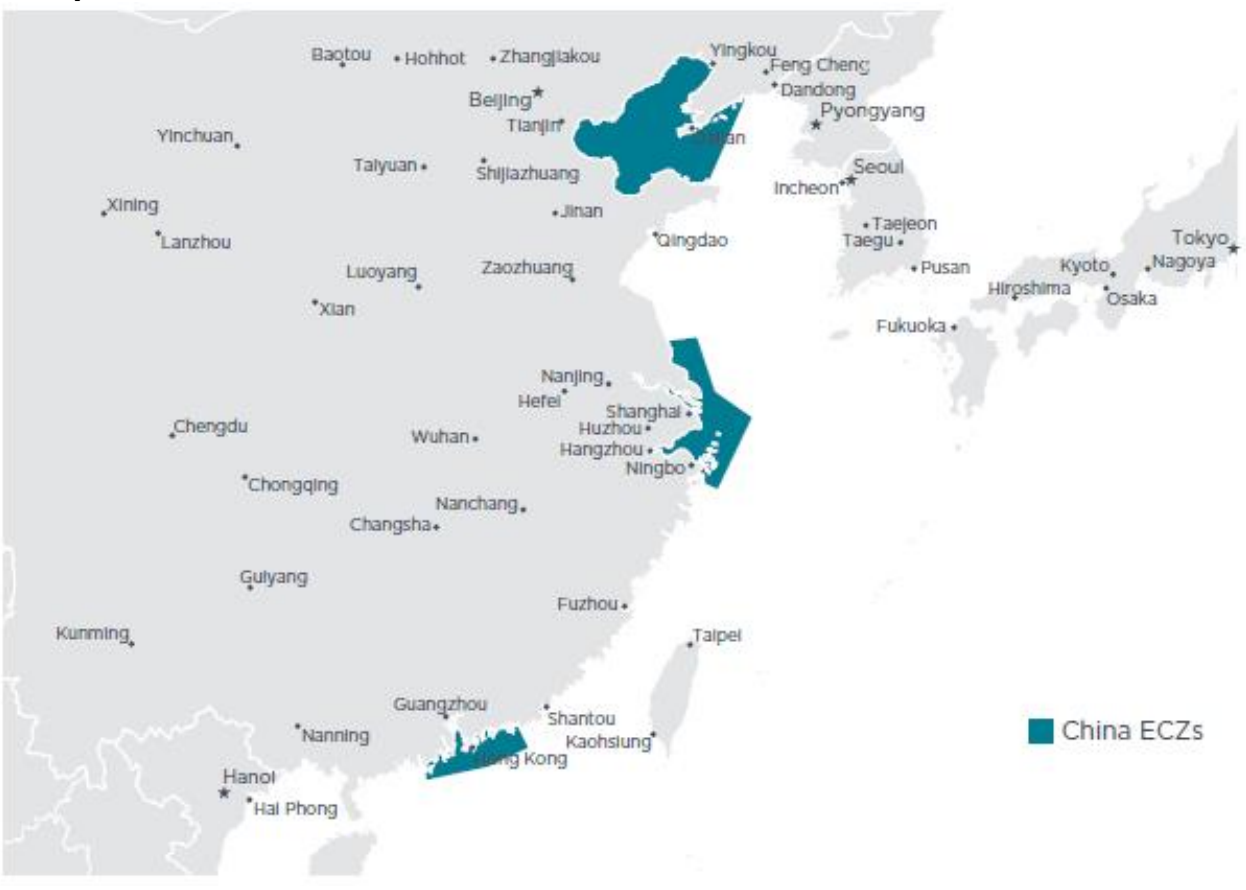

Note: $\mathrm{ECZs}=$ emission control zones.

Source: ICCT.

Building on the SPPPSAP, in December 2015 the MoT released an implementation plan for domestic ECZs, ${ }^{13}$ laying out a more detailed roadmap for achieving the emissions reduction targets within the SPPPSAP and designating 11 'key' ports ${ }^{14}$ within the PRD, YRD, and Bohai Rim.

According to the December roadmap:

- As of 1 January 2017, all ships ${ }^{15}$ calling at the eleven ports in China are required to use fuel with no more than 0.5 per cent sulphur while at berth. The regulation states that ships must switch to compliant fuels within one hour of arriving at their berth and burn compliant fuels until not more than one hour prior to departure.

- A year later, starting 1 January 2018, the at-berth fuel-switching requirement is extended to all ports in the three Chinese port regions (PRD, YRD, and the Bohai Bay). This second step was significant given that these ports together handled more than one-fifth of containers shipped around the world in 2014. ${ }^{16}$

- Then, effective 1 January 2019, the clean fuel requirement is further extended to cover all ships operating anywhere within the ECZs in the three port regions, also covering their territorial waters (12 nautical miles off the coastline), making it the first such mandate outside the EU and North America.

13 PRD, YRD, and Bohai Rim (Beijing-Tianjin-Hebei) waters, http://www.gov.cn/xinwen/2015-12/04/content 5019932.htm. 14 These include Shenzhen, Guangzhou, and Zhuhai in the PRD; Shanghai, Ningbo-Zhoushan, Suzhou, and Nantong in the YRD; and Tianjin, Qinhuangdao, Tangshan, and Huanghua in the Bohai Rim area.

15 The regulation applies to all ships navigating, anchoring, and operating within the ECZs with the exception of military ships, fishing boats, and ships/boats used for sporting purposes.

16 Barbara Finamore, 'China acts to control shipping air pollution and greenhouse gas emissions', NRDC Blog, 8 December 2015, https://www.nrdc.org/experts/barbara-finamore/china-acts-control-shipping-air-pollution-and-greenhouse-gas-emissions. 
- In addition, the plan allowed the 11 'key' ports to enforce the regulation before 1 January 2017. As a result, the YRD introduced the at-berth requirement earlier, on 1 April 2016, and the Shenzhen port in the PRD introduced the mandate on 1 October 2016.

In its 2015 roadmap, the MoT also required a review by the end of 2019 to determine if stricter fuel quality requirements should be imposed. The review took place in late 2018 and created a single domestic emission control area (DECA), expanding coverage of the 2019 requirement from the three port regions to China's entire coastline effective 1 January 2019, 12 months ahead of schedule. This DECA still extends to 12 nautical miles (vs 200 nautical miles in North America), but also includes two stricter emissions control areas in inland waterway systems, the Yangtze River and the Pearl River. The ports of Shanghai, Ningbo-Zhoushan, and Suzhou in the YRD imposed the new caps earlier than this new schedule, implementing them on 1 October 2019. ${ }^{17}$

In addition, the 2018 review phased in emission standards for NOx which were absent from the December 2015 roadmap but required under the SPPPSAP, and set out tighter emissions standards for all China-flagged new-build or rebuilt ships. Finally, unlike the IMO ECA regulations, the 2018 review introduced additional requirements on the installation and use of onshore power, stating that all cruise ships must plug into shore-side electric power beginning on 1 January 2021 if they dock at berths that are shore-power capable. Similarly, shore-power capable ships must be connected to shore-side electricity if they dock at equipped berths starting from 1 July 2019. ${ }^{18}$ Estimates suggest China will have 493 such berths by 2020 .

By expanding the reach of the tighter fuel specifications from regional ECZs to a national DECA, China has effectively become an early adopter of the IMO 2020 sulphur cap while also piloting a 0.1 per cent sulphur requirement for all ships on inland waterways and for ships entering waters off Hainan island, with the latter starting 1 January $2022 .{ }^{19}$ In addition, the 2018 review lays out the potential to introduce more stringent sulphur requirement to the entire national DECA coverage area starting in 2025.20

\section{III. ...but a relatively muted response from refiners}

Despite the changes in domestic regulations, and even though shippers and refiners globally have been active participants in the preparations for the IMO transition and much of the debate on how it would play out, Chinese refiners have seemed less preoccupied with it than their Western peers. This is surprising to some extent. Given that China holds the world's second largest refining capacity behind the US, is home to six of the ten largest container ports globally, and, as detailed above, is an early adopter of tighter shipping fuel emission standards domestically, it should be well ahead of its global peers in its readiness for IMO 2020 and in its ability to supply global markets with IMOcompliant fuels.

While the domestic bunker market has already started its transition to lower sulphur fuels, refiners have played a relatively limited role in supplying that demand. This is in part due to high taxes and onerous export quotas. As a result, a massive outflow of bunker fuels from China is unlikely, at least in the near term. Indeed, the country's MGO production, although plentiful, will struggle to compete internationally due to high consumption taxes on distillates and limited export quotas. And barring a radical change in taxes and export policies, any uptick in Asian diesel cracks related to higher MGO demand may well end up incentivising diesel production and exports, at the expense of MGO. Instead, VLSFO is emerging as the fuel of choice in China. State-owned refiners have announced

\footnotetext{
17 'Chinese ports bring forward marine fuel sulphur cap', Argus, 12 September 2018.

18 Freda Fung and Jingtao Shan, 'China taking further steps to clean up shipping pollution', NRDC blog, 10 January 2019 ,

https://www.nrdc.org/experts/barbara-finamore/china-taking-further-steps-clean-shipping-pollution.

19, 'Action plan for establishing China's National Emissions Control Area', ICCT Policy Update, March 2019,

https://theicct.org/sites/default/files/publications/DECA_China_policy_update_20190304.pdf.

20 'Action plan for establishing China's National Emissions Control Area', ICC T Policy Update, March 2019,

https://theicct.org/sites/default/files/publications/DECA_China_policy_update_20190304.pdf.
} 

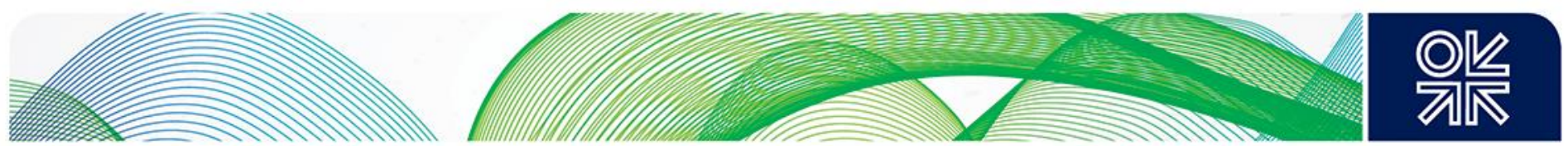

plans to develop close to $20 \mathrm{mt}$ of VLSFO production capacity in 2020 , and have started producing these fuels through 2019, although to date volumes have been minimal, estimated at under $1 \mathrm{mt}$.

So changes are now underway in China's domestic bunkering market and in its refiners' ability to compete in international bunkering, thanks to a combination of favourable tax incentives at ports and a tax rebate on VLSFO exports-which is widely expected in the coming months. In the near term, higher VLSFO output will require some refiners to shift their crude slate to sweeter crudes, which are currently commanding a premium, and squeeze production of clean products, including diesel and gasoline. In 2020, as refiners experiment with VLSFO and seek to establish their position as market leaders, they will continue producing VLSFO even with relatively unappealing economics. Refiners located in coastal provinces and close to the emerging bunkering ports will be best placed to benefit from the IMO transition. As the government continues to ease restrictions on trade in oil products, Chinese refiners and bunkering hubs will emerge as increasingly competitive players in the global bunkering market.

\section{a. A tale of two bunker markets}

The changes domestic regulations have impacted bunker fuel use within the country, although assessing the extent of the change is complicated by limited data. The National Bureau of Statistics (NBS) does not release monthly or quarterly demand data, publishing only lagged annual data, and does not seem to have incorporated demand for MGO in its assessments. ${ }^{21}$

Anecdotal data from the Chinese oil majors and consultancies peg domestic bunker demand at $20 \mathrm{mt}$ in $2018,{ }^{22}$ of which $13 \mathrm{mt}$ consisted of bonded bunker sales at Chinese ports, and an additional 6-7 mt consumed on inland waterways (Figure 2). But unpacking the fuel composition (fuel oil, distillate, and LNG) is extremely challenging given the abovementioned data limitations, exacerbated for refined products by obscure domestic blending practices.

Figure 2: China's bunker demand, mt

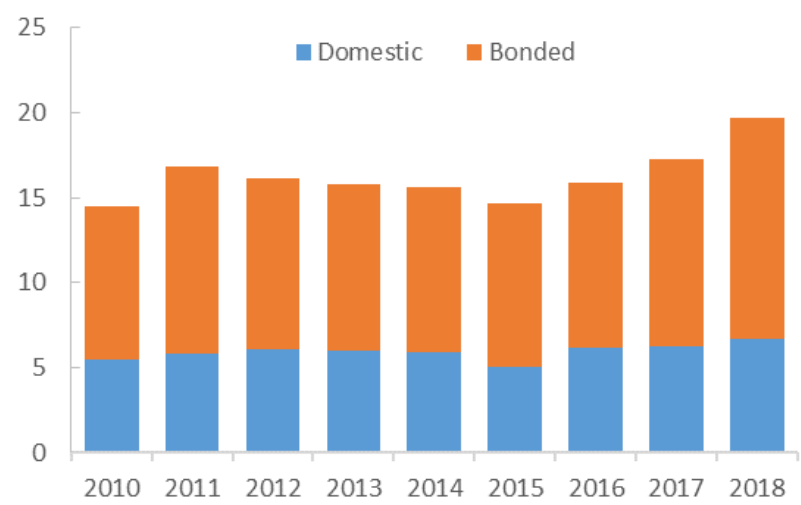

Sources: CNPC, Sinochem, OIES.
Figure 3: Diesel demand by sector, $\mathrm{mb} / \mathrm{d}$

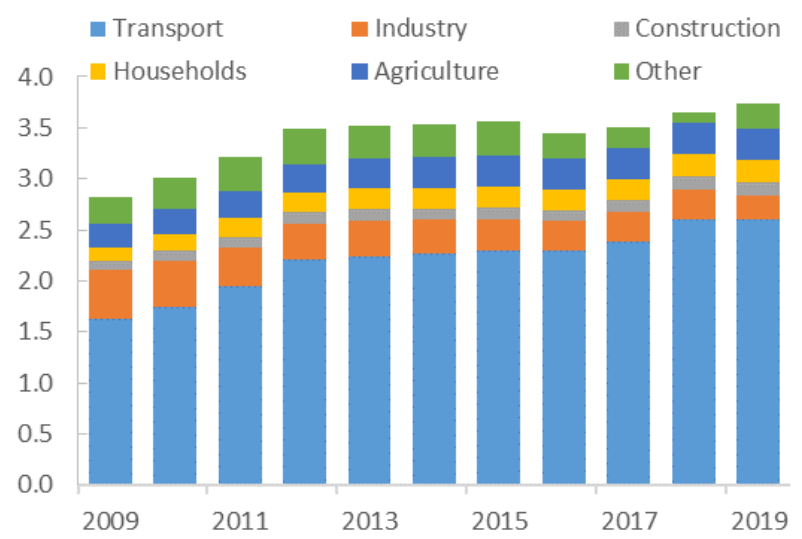

Note: $\mathrm{mb} / \mathrm{d}=$ million barrels per day.

Sources: NBS, CNPC, OIES. 

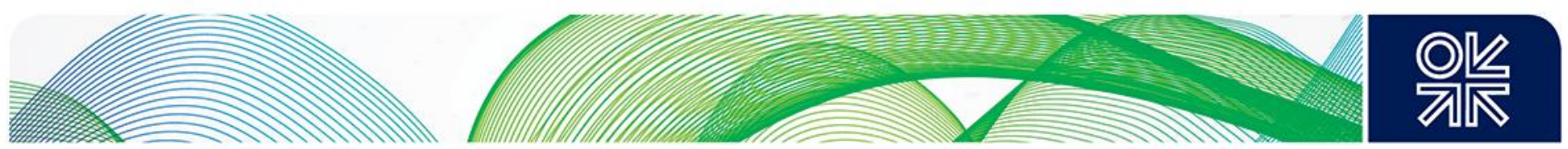

The existing publicly available data sets give a limited sectoral breakdown; so as a result, even though NBS demand data clearly show that the bulk of diesel (Figure 3) and fuel oil (Figure 4) in China are consumed in the transport sector, without a further breakdown between freight and shipping, there are limited ways to gauge changes in fuel oil and MGO demand in domestic bunkering.

Figure 4: Fuel oil demand by sector, $\mathrm{mb} / \mathrm{d}$

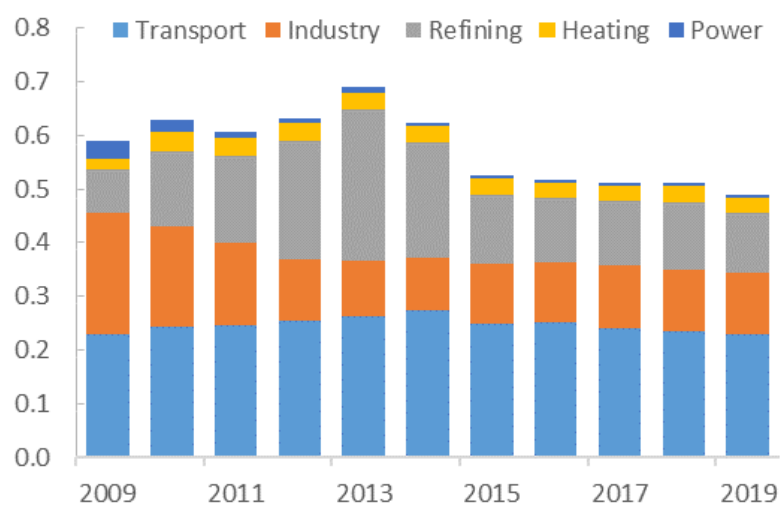

Sources: NBS, OIES.
Figure 5: Freight traffic, billion $\mathrm{mt}$

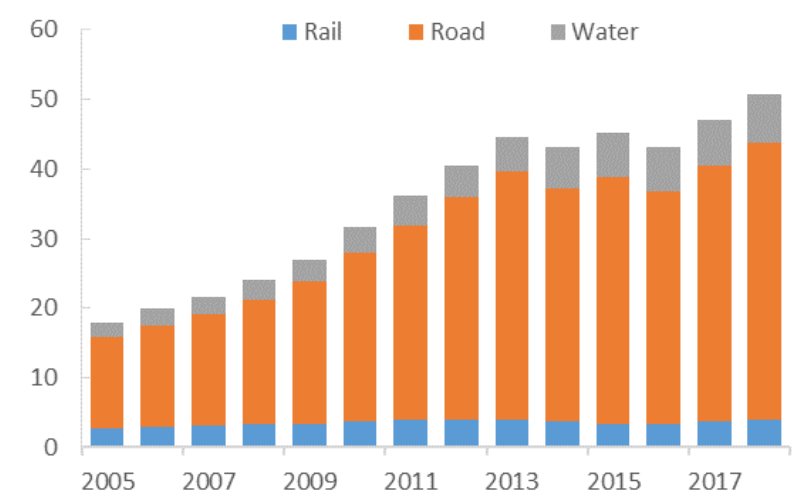

Sources: NBS, OIES.

Fuel oil use in transport has been gradually falling since 2014, when the government began levying consumption tax on it (see below), making it uncompetitive with blended bunker fuels. And while diesel demand in transport has continued to grow, this is due to a combination of higher freight use (from trucks, see Figure 5) and bunkering demand. Unpacking which one has contributed the most to demand growth is challenging.

\section{b. The domestic market is dominated by blenders...}

Refiners claim that only a small percentage of the oil-based bunker fuels are actually produced at refineries, with a large chunk emanating from domestic blending activities. ${ }^{23}$ This is because domestically produced fuel oil incurs a consumption tax of CNY 1,218/tonne ( $\$ 173 /$ tonne $)^{24}$ in addition to VAT at 13 per cent ${ }^{25}$ (Figure 6), making it by and large uncompetitive. 


\section{Figure 6: Fuel oil prices in Shandong, yuan/Mt}

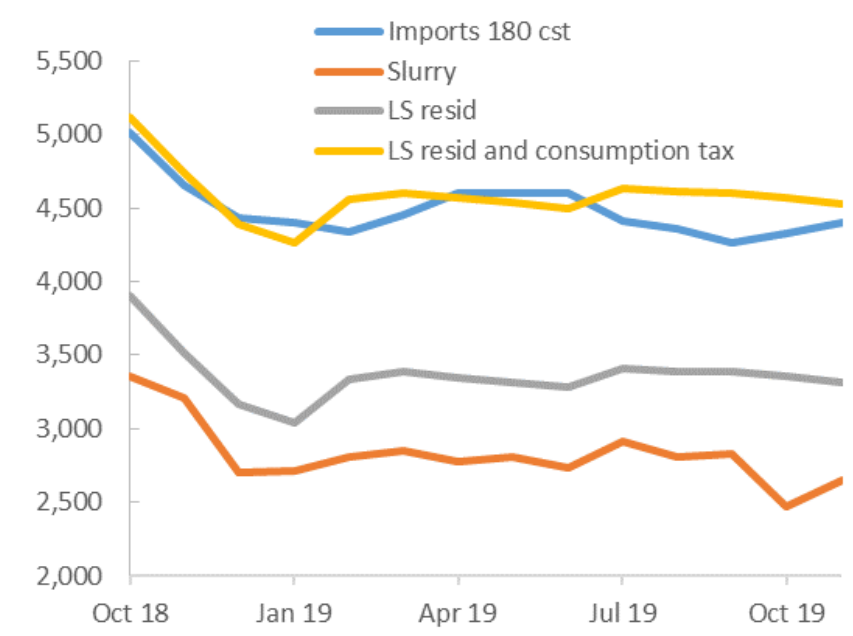

Note: 'LS resid and consumption tax' excludes VAT; cst = centistokes; LS = low-sulphur Source: Oilchem, OIES

This has allowed an active bunker blending market to flourish. In order to achieve the marine fuel oil standard in China, GB 17411-2015, which is reportedly similar to ISO $8217,{ }^{26}$, domestic blenders can use a variety of components, mixing residue streams (including slurry and asphalt) with various cutter stocks and by-products, such as paraffin and coal-based liquids, in order to produce competitively priced fuels. It is also common to blend one part jet fuel with three parts light cycle oil (LCO) in south and east China to produce bunker fuels or gasoil. ${ }^{27}$

For now, therefore, domestic bunkering seems to rely more heavily on refinery-produced distillates than on fuel oil-likely due to tax evasion that makes them more competitive. But as China is shifting to $0.1 \mathrm{ppm}$ in inland waterways on 1 January 2020 and the government is cracking down on tax evasion, fuel oil demand could rise, given also that shippers are increasingly finding MGO viscosity unsuitable ${ }^{28}$.

In the interim, with tighter fuel specifications and more stringent enforcement (of both fuel quality and tax rules), it will become harder for blenders to operate and the state-owned refiners are likely to regain market share in domestic bunkering. As the majors increase production of VLSFO, and some use HSFO as an intermediate product, they will sell less HSFO and other blending components to domestic blenders. Moreover, as the government is also encouraging LNG in shipping (see below on LNG bunkering), demand for distillate-based bunker fuels is likely to fall further, leaving the competition between LNG and resid-based bunker fuels down to the state-owned majors' development strategies, as they are likely to emerge as the main suppliers of both VLSFO and LNG.

\section{c. ....and the bonded market is dominated by imports}

The high costs of producing bunker fuels for the domestic market have also made them uncompetitive in China's bonded market, with the export quota system further hindering outflows. The government manages product exports with two different licensing schemes: 'tolling' quotas and 'general trade' quotas. Under the former, refiners import crude explicitly in order to process it and re-export the products, so refiners are exempted from import taxes on the crude oil as well as from export duties on the oil products. But they are allocated a fixed volume and time slots to export, both under the tight

\footnotetext{
26 China's diesel fuel specifications can be found here:, https://www.dieselnet.com/standards/cn/fuel.php.

27 'New refineries eye marketing options', Argus, 1 March 2019.

28 “'Shippers must prepare as China shifts to $0.1 \mathrm{ppm}$ fuels in inland waterways'waterways" (Chinese), Hyqfocus,

https://www.hyqfocus.com/jsp/model.jsp?id=1685\&modelType=2.
} 

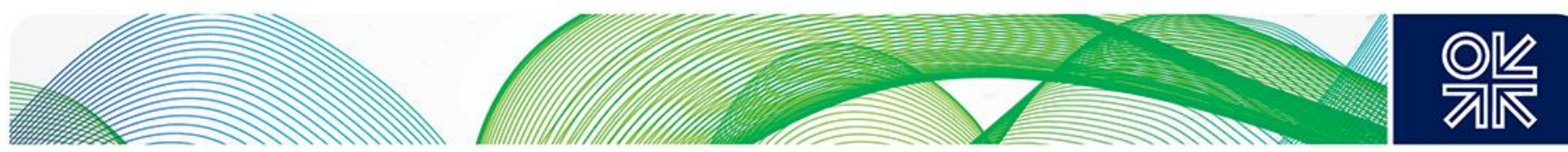

scrutiny of the Chinese customs administration, which has reportedly made this system inflexible and onerous. ${ }^{29}$ Under the 'general trade' category, state-owned refiners are free to export regardless of whether the feedstock is domestic or imported and, since 2016, refiners are refunded tax after exports are completed or receive a tax waiver on fuel exports. As such, up until 2017 the bulk of the export quotas were under the tolling route, but since 2017 the government has reduced the tolling quotas significantly, favouring the general trade route (Figure 7). Bonded bunker fuels are therefore essentially imported fuel and blendstock, which tend to be more competitive than domestic fuels. ${ }^{30}$

Figure 6: Export quotas, mt

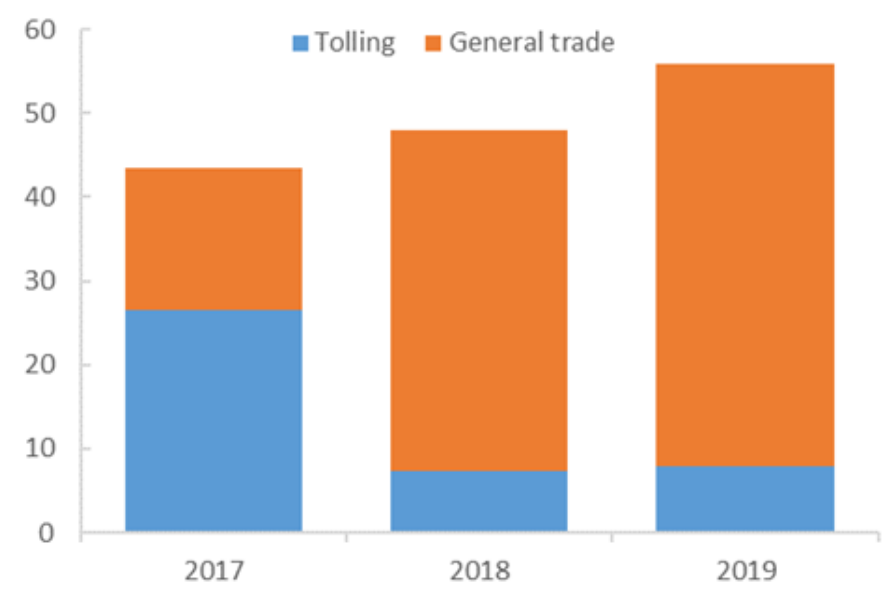

Sources: MOFCOM, OIES.

Exports of gasoline, diesel, and jet are determined by the quotas, which are typically issued on a quarterly basis, with any unused quotas rolled over to the next quarter, but not to the following year. Fuel oil exports are not regulated, but under the 'tolling' system, refiners also have a small percentage earmarked for 'other products' which typically includes fuel oil. Refiners can therefore export small volumes of fuel oil tax-free, but as volumes of 'tolling' quotas have fallen, so have the favourable tax conditions for selling fuel oil internationally.

As a result, China's bonded bunker market relies heavily on imports-almost 90 per cent of bunker fuel imports in 2018 were 380cst HSFO, alongside more limited volumes of MGO, as well as 180cst and 500cst HSFO. But only an estimated $0.6 \mathrm{mt}$ (or around 10-15 thousand barrels per day (kb/d)) of MGO were sold that year from bonded storage tanks. ${ }^{31}$ Indeed, distillate-based bunker fuels face similar constraints. Domestically produced MGO incurs an even higher consumption tax than fuel oil, at CNY 1,411/tonne (\$200/tonne), and so any exports would need to be competitive from that price point, especially since MGO exports would also eat away at refiners' distillate export quotas.

A combination of changing domestic dynamics-including the ongoing tax crackdowns and more stringent enforcement of tighter fuel specifications domestically-alongside the state-owned refiners' efforts to increase their production of VLSFO, will make China a more active participant in the international bunkering market. The government is widely expected to announce tax rebates for VLSFO exports in the coming months, although these are likely to be governed by an export quota system to begin with. Nonetheless, refiners anticipate that the tax rebates will make their VLSFO more competitive, effectively breaking the tax barrier standing between them and the global bunkering

29 While this has been an appealing tax-saving method for Sinopec, which relies on imported crude, it has been less advantageous for PetroChina, which relies more heavily on domestic crudes for its refineries.

30 http://www.xindemarinenews.com/m/view.php?aid=10860.

31 'Chinese ports bring forward marine fuel sulphur cap', Argus, 12 September 2018. 
market. At the same time, the advent of FTZs may encourage blenders to move their activities to these bonded zones, shifting competition with state-owned refiners producing VLSFO away from the domestic market. Refiners, however, also have considerable distillate production capacity and even though the current export quota system makes it hard for them to respond quickly to Asian price signals, should diesel cracks surge in 2020 , they will be able to capitalize on an MGO-led IMO transition, albeit at the margins. In the next section, we discuss domestic product output and the implications of the IMO transition for refiners.

\section{China's refiners gear up for IMO 2020}

China has ample capacity, at least in theory, to produce IMO compliant fuels. The country's nameplate refining capacity in 2019 is estimated at $16.7 \mathrm{mb} / \mathrm{d}$, with an additional $0.4-0.5 \mathrm{mb} / \mathrm{d}$ of new crude distillation units planned for $2020 .{ }^{32}$ China's refining system has traditionally been geared toward producing industrial fuels, using medium and heavy crudes as feedstock. As a result, diesel yields at their peak in 2006 reached 40 per cent, and have since fallen to around 33 per cent, while fuel oil yields peaked in the late 1990 s at close to 10 per cent, dropping subsequently to under 4 per cent in 2018.

As China's domestic economic structure began moving away from its reliance on industrial production to a growing demand for consumer goods, so too has demand for oil products shifted from the middle and bottom of the barrel toward light ends. In light of this, the government and state-owned refiners have long been targeting a reduction in diesel yields in favour of gasoline (Figure 8), given expectations that rising car ownership would support gasoline demand and a gradual shift away from industrial activity as the mainstay of the Chinese economy would weaken demand for diesel. Similarly, fuel oil demand in industry and power has declined, while jet fuel yields have grown to service the country's growing air transport needs (Figure 9).

Figure 7: China diesel and gasoline yields, \%

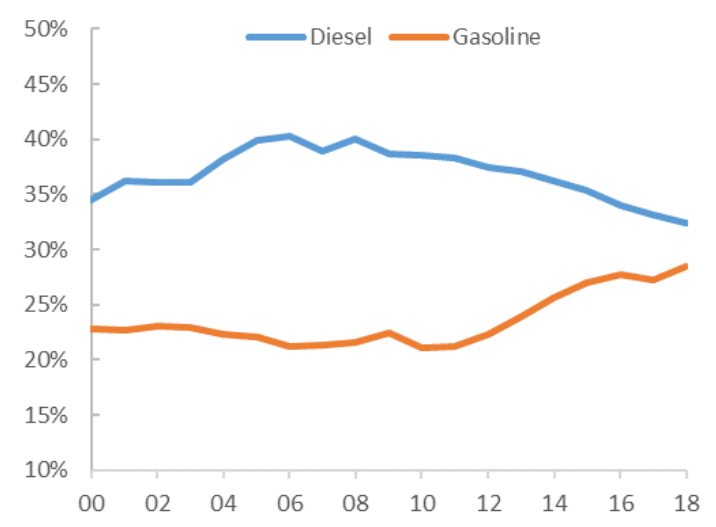

Sources: NBS, OIES.
Figure 8: China jet and fuel oil yields, \%

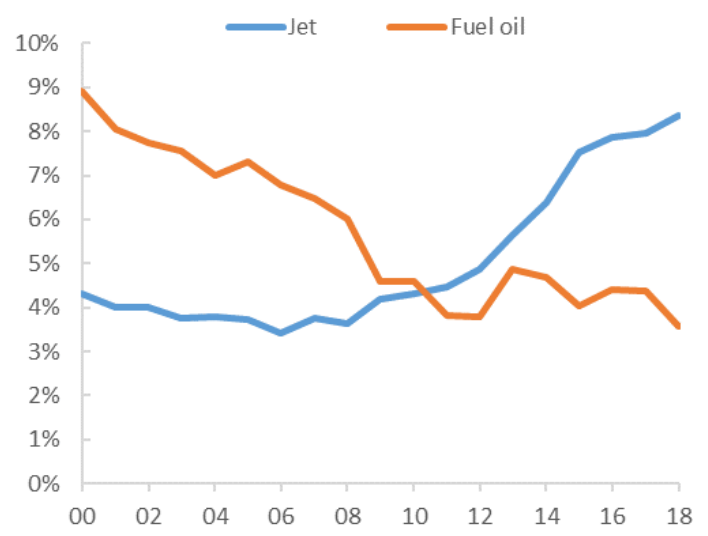

Source: NBS.

\section{a. Large distillate and resid production capacity...}

It is important to note that even as diesel yields have fallen, China's overall installed refining capacity has increased, so diesel output has continued to grow, rising from $2.3 \mathrm{mb} / \mathrm{d}$ in 2005 to $3.6 \mathrm{mb} / \mathrm{d}$ in 2018 according to the NBS. That said, domestic product output and runs data have been skewed,

\footnotetext{
32 Assuming that not all plants start up and run at full capacity. Planned additions include the following: Rongsheng is starting up its second $0.20 \mathrm{mb} / \mathrm{d}$ crude distillation unit in $\mathrm{H} 120$; Sinopec is starting up its $0.20 \mathrm{mb} / \mathrm{d}$ Zhanjiang plant (Zhongke) in $\mathrm{H} 220$ as well as a $40 \mathrm{~kb} / \mathrm{d}$ expansion to its Luoyang refinery; Sinochem is planning an additional $60 \mathrm{~kb} / \mathrm{d}$ at Quanzhou; while a number of independents are planning close to $0.20 \mathrm{mb} / \mathrm{d}$ of new capacity.
} 

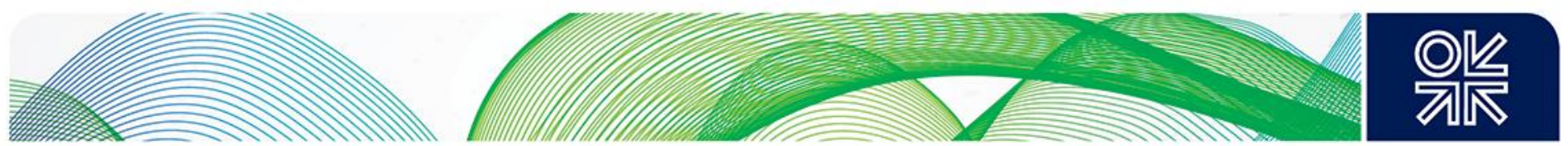

especially between 2016 and 2018, as the Shandong independent refiners misreported their crude throughputs for tax evasion purposes. ${ }^{33}$ During these years, Shandong runs were most likely understated, with estimates of the misreporting ranging from $0.3 \mathrm{mb} / \mathrm{d}$ to as much as $0.8 \mathrm{mb} / \mathrm{d}$. Starting in 2018 the government reformed its tax collection system, ${ }^{34}$ and by introducing an online tax platform has eliminated the use of fake invoices, suggesting that runs reporting has become more accurate. In response, as the market for fake invoices for crude dried up, parts of the products market have moved outside of the tax system, with refiners selectively issuing invoices for products sold to private retailers at the refinery gate, ${ }^{35}$ especially for off-road diesel and potentially bunker fuels, given that these customers do not require invoices but do favour lower costs.

The clearest manifestation of this latest discrepancy in product output has been the collapse of diesel yields in Shandong, home to many of China's independent refiners. Indeed, diesel yields plummeted from an average of 47 per cent in 2017 to 34 per cent in 2018 and then to 23 per cent in 2019, even as provincial runs continued to rise (see Figure 10).

Figure 9: Shandong diesel yields, \%, runs, mb/d

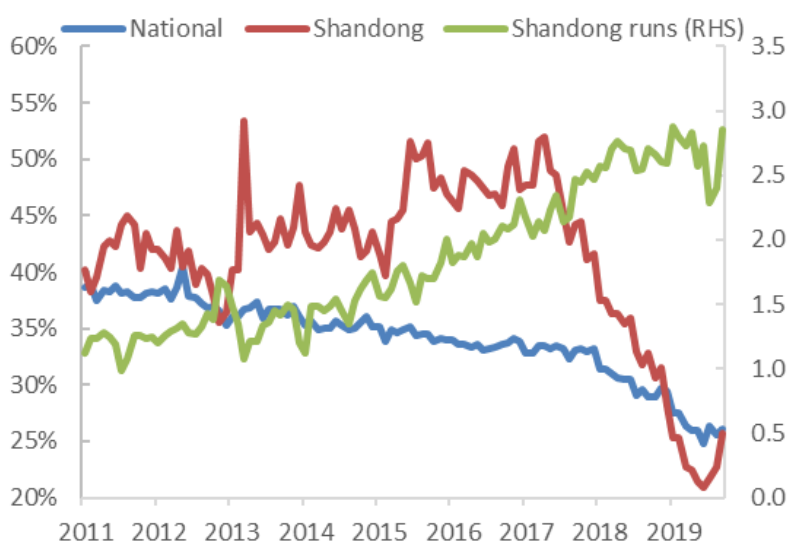

Sources: NBS, OIES.
Figure 10: China's diesel production, $\mathrm{mb} / \mathrm{d}$

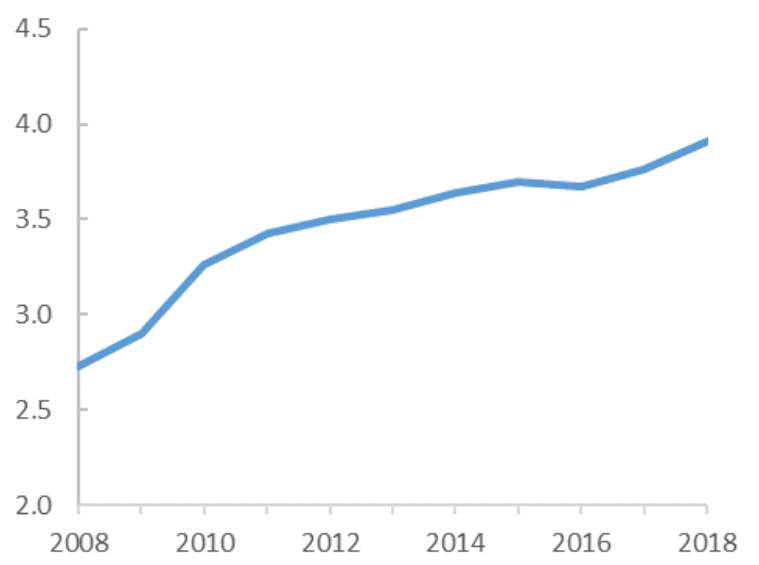

Note: Includes adjustment for underreported diesel output Source: NBS.

A number of reports and conversations with independent refiners suggest that diesel yields have not fallen dramatically and some refiners note that they actually raised diesel yields in 2019, in response to strengthening prices. ${ }^{36}$ Assuming historical average diesel yields in Shandong province of 43 per cent and applying them to 2019 , suggests that some $0.4 \mathrm{mb} / \mathrm{d}$ of diesel production is underestimated by official data in China. So, when accounting for underreported runs and output, diesel yields are still in decline, but domestic output is growing (Figure 11). Chinese refiners clearly have the capacity to produce distillate-based bunker fuels, but only output in Liaoning province and in the YRD have easy access to export markets. A third of the total diesel produced in China is in the northern parts of the country (North ex-Shandong and North East in Figure 12) and an additional 21 per cent is produced in Central and Western China. Oil product transport and distribution infrastructure in these provinces has been built to encourage flows of crude and products from coastal areas further inland, rather than

\footnotetext{
33 See: Michal Meidan, 'China's independent refiners: A new force shaping global oil markets', Energy Insight 12, May 2017, https://www.oxfordenergy.org/wpcms/wp-content/uploads/2017/05/Chinas-Independent-Refiners-A-New-Force-Shaping-GlobalOil-Markets-OIES-Energy-Insight.pdf?v=79cba1185463; Erica Downs, 'The rise of China's independent refineries', Center on Global Energy Policy working paper, September 2017,

https://energypolicy.columbia.edu/sites/default/files/CGEPTheRiseofChinasIndependentRefineries917.pdf.

34 Oceana Zhou, 'Beijing charges ahead with administrative reforms to eliminate oil tax loopholes', S\&P Global Platts, 1 March 2018, https://blogs.platts.com/2018/03/01/beijing-reforms-eliminate-oil-tax-loopholes/.

35 'China NBS data take a turn for the worse', Argus, 26 July 2019.

36 'Demand revision suggests little slowdown for diesel', Argus, 28 August 2019.
} 
from these areas to export markets, and therefore land-locked refiners traditionally prioritize their local markets. In 2017, for example, diesel exports out of Beijing-Tianjin-Hebei accounted for only 6 per cent of the national total (North ex-Shandong in Figure 13).

The largest diesel-producing province is Shandong at $0.9 \mathrm{mb} / \mathrm{d}$, or 25 per cent of total diesel production in China in 2017, where the independent refiners tend to sell off-road diesel to industrial users, domestic blenders and the majors' sales arms. As they have limited retail outlets and no export quotas (for now), the independents would need to rely on the majors for export logistics to tap into the international bunker market, and this would be likely to incur even higher costs. As a result, Shandong province accounted for only 7 per cent of the country's total diesel exports in 2017 . One of the largest export provinces is Liaoning, where diesel production reached $0.4 \mathrm{mb} / \mathrm{d}$ in 2018, or 12 per cent of domestic output. Given these refiners' proximity to a large bunkering hub in Dalian, in 2017 they accounted for a quarter of total diesel exports.

Finally, refiners near the country's main waterways have large production volumes that could be diverted inland or overseas. In the YRD (Shanghai, Jiangsu and Zhejiang), refiners accounted for 11 per cent of diesel output and 22 per cent of diesel exports in 2017. In Guangdong (9 per cent of domestic production), at the mouth of the PRD, refiners accounted for 12 per cent of China's diesel exports in 2017.

Figure 11: Diesel production by region $2017, \%$

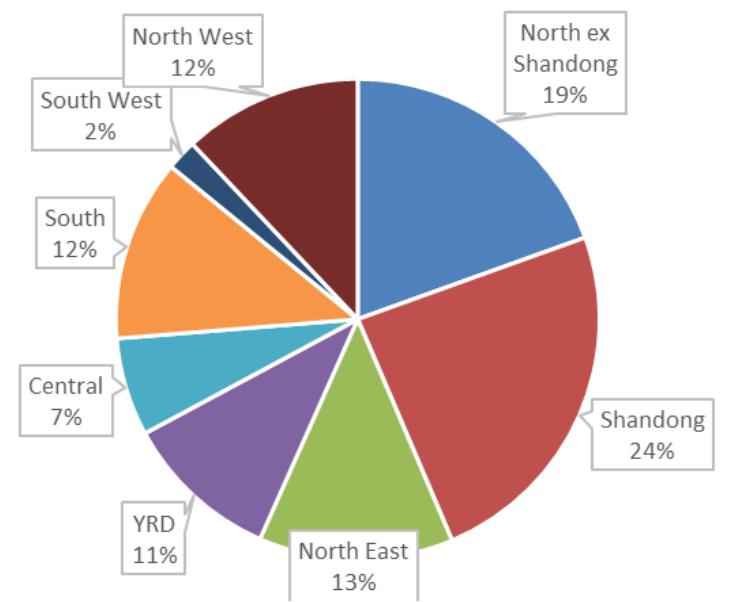

Note: Includes adjusted for underreported diesel output.

Sources: NBS, OIES.
Figure 12: Diesel exports by region 2017, \%

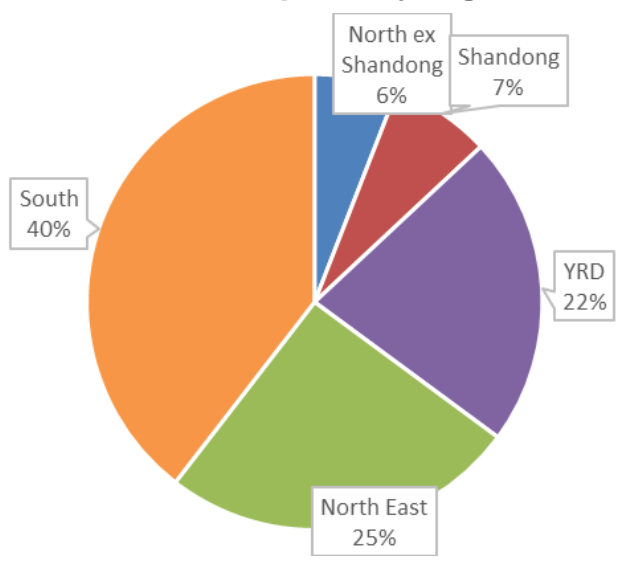

Note: Customs stopped publishing detailed export data in 2018.

Sources: China Customs, Argus, OIES.

The geographic mismatch between production and export infrastructure has constrained diesel exports historically and is therefore likely to act as a barrier to large volumes of MGO exports. If Asian diesel cracks supported it, however, China's coastal refiners should be able to produce MGO for export, but the diesel export market is far bigger and more profitable, and so using export quotas for that makes more sense than for MGO.

\section{b. ... but China's refiners are focusing on VLSFO}

For now, given high demand and prices (VLSFO prices are not far below those for MGO), fuel oil is emerging as state-owned refiners' favoured option in response to the opportunities that the new IMO regulations present. Output in the YRD-mainly in Zhejiang province, where the Zhoushan FTZ and bunkering hub is located-has been picking up substantially in recent months (Figure 14). The vast majority of fuel oil production remains in Shandong, although the independent refiners' enthusiasm for producing bunker fuels has been muted, to date. 

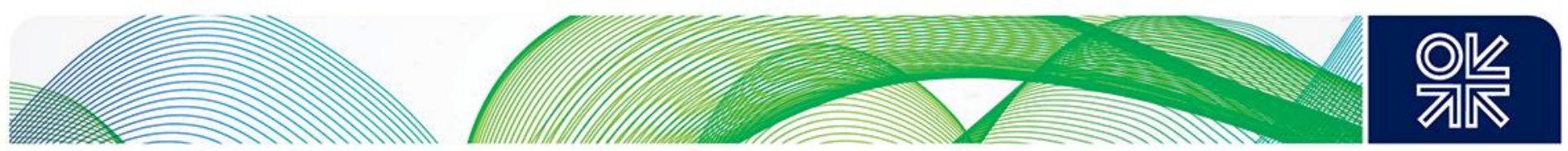

Figure 13: Fuel oil production by region, $\mathrm{mb} / \mathrm{d}$

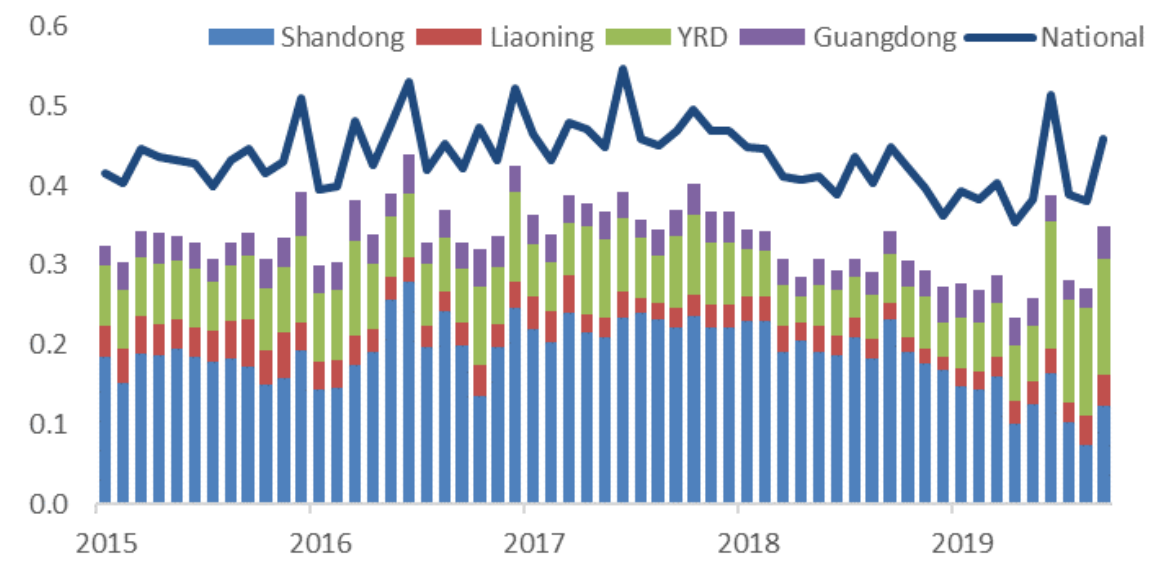

Source: NBS.

Contrary to diesel, China's fuel oil production has been relatively flat at around $0.45 \mathrm{mb} / \mathrm{d}$ between 2013 and 2018, while imports have dropped as demand started slowing. But the arrival of IMO 2020 is leading to a tentative reversal in fuel oil's fortunes. Here too, there is no official data on VLSFO production as a share of total fuel oil output, but there are plenty of announcements from the stateowned refiners suggesting they will increasingly emphasize VLSFO:

- Sinopec has announced it will have $10 \mathrm{Mt}$ of VLSFO capacity by 2020 , increasing to $15 \mathrm{Mt}$ by 2023 from ten refineries (Table 1).

- PetroChina is gearing up for $4 \mathrm{Mt}$ of VLSFO output in 2020 from eight plants, doubling that production capacity in 2021.

- CNOOC plans to produce 3.6 Mt in 2020, and is reportedly capable of producing $1.7 \mathrm{Mt}$ already, increasing its output to $6 \mathrm{Mt}$ in 2022.

- Finally, Sinochem is planning $0.55 \mathrm{Mt}$ of output in 2020 from its Quanzhou refinery, rising to $1 \mathrm{Mt}$ in 2021.

- Combined, therefore, China's state-owned majors aim to produce just over $18 \mathrm{Mt}$ of VLSFO in 2020,37 which falls only slightly short of overall demand within the country, before increasing to close to $23 \mathrm{Mt}$ in 2021, $25 \mathrm{Mt}$ in 2022 and a massive $30 \mathrm{Mt}$ by 2023. 
Table 1: Sinopec and PetroChina refineries producing IMO-compliant VLSFO

\begin{tabular}{|c|c|c|c|c|c|c|}
\hline $\begin{array}{l}\text { Refinery } \\
\text { name }\end{array}$ & Location & $\begin{array}{l}\text { Name- } \\
\text { plate } \\
\text { kb/d }\end{array}$ & $\begin{array}{l}\text { Resid } \\
\text { hydro } \\
\text { kb/d }\end{array}$ & $\begin{array}{l}\text { VLSFO } \\
\text { volume } \\
\text { (mt) }\end{array}$ & $\begin{array}{l}\text { Supply } \\
\text { start date }\end{array}$ & Crude slate \\
\hline \multicolumn{7}{|c|}{ Sinopec Refineries } \\
\hline $\begin{array}{l}\text { Shanghai } \\
\text { Petrochemical }\end{array}$ & Shanghai & 320 & 78 & 6,000 & Jan 19 & Light, medium imports \\
\hline $\begin{array}{l}\text { Jinling } \\
\text { Petrochemical }\end{array}$ & Jiangsu & 380 & 70 & 8,000 & May-19 & Sour imports \\
\hline $\begin{array}{l}\text { Zhenhai } \\
\text { Refining }\end{array}$ & Zhejiang & 460 & $\begin{array}{l}50(50 \\
\text { in Dec } \\
19)\end{array}$ & & $\begin{array}{l}\text { Ready to } \\
\text { start }\end{array}$ & Sour imports \\
\hline $\begin{array}{l}\text { Qilu } \\
\text { Petrochemical }\end{array}$ & Shandong & 370 & 52 & $\begin{array}{l}\text { Tested } \\
\text { stability }\end{array}$ & Aug 2019 & $\begin{array}{l}\text { Middle East, WAF } \\
\text { imports }\end{array}$ \\
\hline Tianjin & Tianjin & 300 & 26 & & 2020 & $\begin{array}{l}\text { Local Dagang (sweet) } \\
\text { sweet crude imports }\end{array}$ \\
\hline $\begin{array}{l}\text { Qingdao } \\
\text { Petrochemical }\end{array}$ & Shandong & 100 & 26 & 5,000 & Nov 2019 & Sour imports \\
\hline $\begin{array}{l}\text { Zhanjiang } \\
\text { Dongxing }\end{array}$ & Guangdong & 100 & & & 2020 & $\begin{array}{l}\text { Imports from Angola, } \\
\text { Gabon, Ghana }\end{array}$ \\
\hline Maoming & Guangdong & 470 & $\begin{array}{l}40(80 \\
\text { in 2020) }\end{array}$ & & $\begin{array}{l}\text { Ready to } \\
\text { start }\end{array}$ & $\begin{array}{l}\text { Sour crudes, Middle } \\
\text { East }\end{array}$ \\
\hline $\begin{array}{l}\text { Hainan } \\
\text { Refining and } \\
\text { Chemical }\end{array}$ & Hainan & 160 & & 2,200 & Feb 2019 & $\begin{array}{l}\text { Imports, Middle East, } \\
\text { Angola }\end{array}$ \\
\hline $\begin{array}{l}\text { Zhanjiang } \\
\text { (Zhongke) }\end{array}$ & Guangdong & 200 & & & H2 2020 & Kuwaiti crude \\
\hline \multicolumn{7}{|c|}{ PetroChina refineries } \\
\hline $\begin{array}{l}\text { Liaohe } \\
\text { Petrochemical }\end{array}$ & Liaoning & 100 & & 4,500 & Apr 2019 & $\begin{array}{l}\text { Domestic sweet } \\
\text { crudes }\end{array}$ \\
\hline Liaoyang & Liaoning & 200 & & 3,200 & Nov 2019 & $\begin{array}{l}\text { Domestic, Russian } \\
\text { crude }\end{array}$ \\
\hline $\begin{array}{l}\text { Dalian } \\
\text { Petrochemical }\end{array}$ & Liaoning & 410 & 60 & 3,500 & Jun 2019 & Daqing, WAF \\
\hline $\begin{array}{l}\text { Dalian } \\
\text { WEPEC }\end{array}$ & Liaoning & 200 & 40 & & & Sour imports \\
\hline $\begin{array}{l}\text { Jinzhou } \\
\text { Petrochemical }\end{array}$ & Liaoning & 180 & $\begin{array}{l}(30 \mathrm{in} \\
2020)\end{array}$ & & $\begin{array}{l}\text { Ready to } \\
\text { start }\end{array}$ & $\begin{array}{l}\text { Domestic sweet, } \\
\text { imports Chad, Russia }\end{array}$ \\
\hline $\begin{array}{l}\text { Guangxi } \\
\text { Petrochemical }\end{array}$ & Guangxi & 240 & 80 & 3,000 & Aug 2019 & Light sweet \\
\hline Dagang & Tianjin & 100 & & & & Domestic Dagang \\
\hline $\begin{array}{l}\text { Jinxi } \\
\text { Petrochemical }\end{array}$ & Liaoning & 130 & & & $\begin{array}{l}\text { Ready to } \\
\text { start }\end{array}$ & Domestic \\
\hline
\end{tabular}

Notes: Resid hydrotreating capacity in brackets denotes additional unit capacity; WAF = West Africa; WEPEC = West Pacific Petrochemical Co.

Sources: Company reports, SCI, Argus, OIES. 
Of these plants, eight have already produced VLSFO and sold it to bunkering hubs. Given these refiners' different levels of complexity and crude slates, their VLSFO production strategies will vary, but most that have now started producing VLSFO need to tweak their crude slates and product yields, without requiring substantial secondary unit upgrades. Chinese refiners hold an estimated $5.5 \mathrm{mb} / \mathrm{d}$ of hydrotreating capacity, more than half at Sinopec refineries, which are also well equipped with residue hydrotreating units, allowing them to produce low-sulphur slurry oil for use in bunkering (see Table 1).

Sinopec's Jinling, Zhenhai, Hainan, and Qilu refineries, as well as PetroChina's Guangxi refinery, are seeking to sweeten their crude slates, which will give them a steady source of low-sulphur vacuum gasoil (VGO) to blend into VLSFO. ${ }^{38}$ Sinopec's Zhanjiang Dongxing Petrochemical and PetroChina's Liaohe Petrochemical already run sweet crudes. Zhanjiang Donxing relies on imports from Angola, Gabon, and Ghana, allowing it to blend slurry oil, vacuum residue, and catalytic gasoil to produce onspec VLSFO. Liaohe Petrochemical processes sweet domestic crudes that are well suited to producing IMO-compliant VLSFO.

Overall, PetroChina refineries that run on domestic low-sulphur crudes will be able to produce VLSFO without substantial unit upgrades. Liaohe crude, for example, has a sulphur content of 0.34 per cent while Daqing has 0.11 per cent and Daqing Blend has 0.18 per cent. ${ }^{39} \mathrm{CNOOC}$ refineries also run low-sulphur crudes from offshore fields in the Bohai Sea. So, while some refiners will need to tweak their crude slates, for most others the main issue will be the loss of intermediates, including VGO and residue oil, which will squeeze output of other high-value refined products such as gasoline and gasoil in favour of VLSFO.

Estimates peg the loss of gasoil and diesel-for production of $10 \mathrm{mt}$ of VLSFO-at $5 \mathrm{mt}$ combined,40 with gasoline accounting for over $3 \mathrm{mt}$ of that reduction. Considering that in 2018 China produced 140 $\mathrm{mt}$ of gasoline and $170 \mathrm{mt}$ of diesel, a $5 \mathrm{mt}$ loss overall would have a limited impact on product supply. However, given that fewer than 20 refineries (out of over 150 in the country) will shoulder this loss, the economic upside for these refiners will need to be significant over time. To be sure, in the first few months, as these plants seek to experiment with VLSFO output and establish themselves as market leaders, they will pursue VLSFO production with limited regard for the economics-especially since VLSFO production volumes have thus far been limited (under $1 \mathrm{mt}$ ), and therefore the loss of clean product is also limited. In Q4 19, losing some output will not an issue as domestic gasoline demand weakens seasonally, but in Q1 20, peak transport fuel season, the decision to prioritize VLSFO output may be more complicated, especially since the Shandong teapots and the new megarefineries could look to produce more gasoline and diesel at the expense of the majors.

The Shandong independents could also test their mettle in low-sulphur bunker fuels, but most of them will need to invest in additional secondary units. They have added an estimated $70 \mathrm{~kb} / \mathrm{d}$ of residue hydro treating capacity and plan to add close to $0.2 \mathrm{mb} / \mathrm{d}$ through 2020. But in recent years most of their unit additions have been delayed cokers, reformers, hydrocrackers as well as gasoline and diesel hydrotreaters. ${ }^{41}$ Given the majors' dominance of the VLSFO market and uncertainty surrounding MGO demand, and in light of the current domestic credit squeeze and their dire finances, they may hold off additional investment plans. That said, the Shandong independents also fear that the sweet crude imports they favour will become increasingly costly post-2020, so retooling their plants to run sourer crude may become a more appealing option in 2020. Currently, Shandong refiners are biased toward deep conversion, with 23 per cent coking relative to primary capacity compared with an average of 13 per cent in the rest of China. This absorbs large amounts of residue, but leaves petroleum coke. The Shandong teapots also sell some of their fuel oil as bunkering

\footnotetext{
38 In spite of high premiums for these crudes, the economics are compelling: in early December $2019,0.5$ per cent sulphur marine fuel was fetching a $\$ 284 / \mathrm{mt}$ premium to Platts 380 cst HSFO, up from $\$ 44.50 / \mathrm{mt}$ on 2 January 2019 when Platts started assessing cargoes of IMO-compliant bunker fuels (Bunkerwire, 4 December 2019).

39 According to SCl.

40 This view is also echoed by domestic shippers: 'The fuel oil export rebate policy offers opportunities and challenges for domestic refiners' (Chinese); Argus China Petroleum, November 2019, p. 6.

41 'Bunker rules spur Shandong residue rethink', Argus, 30 November 2018.
} 
blendstock given that it is mostly made up of oil slurry, which typically has sulphur content of less than 2 per cent but higher than 0.5 per cent, and is used in bunker fuel blending. Given tightening environmental scrutiny and falling demand for petcoke, the independents could gradually look to boost bunker fuels. They are likely to wait and see how the market shapes up - given the majors' first mover advantage-and whether or not they can benefit from the government's tax rebate policy. If it is extended only to the state-owned majors, they are more likely to hold off retooling for bunker fuels. Ultimately, then, much will depend on the tax rebate system.

\section{New tax scheme and FTZs support VLSFO production and exports}

For China's state-owned refiners, despite the emerging strength in VLSFO prices globally, the economics of producing and exporting VLSFO remain weak, and all eyes are on the government's tax rebate scheme. A handful of refiners already have tolling quotas that they can use to export VLSFO, including PetroChina's Dalian WEPEC, which can export fuel oil components to bonded warehouses. However, for China's bonded bunker market to take off, more refiners will need favourable tax conditions.

As mentioned above, Chinese refiners and blenders are unable to claim back consumption and valueadded taxes on domestic fuel sold as bonded bunker fuel, putting them at a significant cost disadvantage to suppliers in Singapore. The government was expected to announce a tax rebate on bonded low-sulphur marine fuel sales in $\mathrm{H} 219$, then towards the year end, and while the rebate scheme is currently with government bureaucracies for final approval, it is making its way very slowly through the system. The tax rebates will undoubtedly be released, but to begin with they may also include quotas (rather than an automatic rebate for any exporter) and could be restricted to the FTZs (such as Zhoushan), only to be expanded gradually.

In addition to onerous taxes, China's policies around blending imported fuel components have been quite restrictive. Zhoushan port, part of the Zhejiang FTZ, is the exception. ${ }^{42}$ Bunker fuels can be taken from Zhoushan bonded storage and sold to other customs administrations. Bunker transactions can also take place at five 'outer anchorages' off Zhoushan where ships can refuel without docking. Back in 2017, Zhoushan licensed five regional bunker fuel suppliers to transact in the FTZ, doubling the number of companies permitted to supply bunker fuels nationally and introducing some competition into a monolithic sector. ${ }^{43}$ In 2018 , the government allowed bunkering firms to blend onspecification product with imported blendstocks, meaning that local firms could blend locally. These policies, and the advantages Zhoushan receives through its status as an FTZ, have allowed it to lower prices relative to other ports and drive down bunkering costs.

But for Zhoushan to become a key bunkering hub as IMO 2020 approaches, China will need to produce and export indigenous product. The tax rebate policy will therefore be critical in determining the competitiveness of China's refinery-based bunker fuels vs blending at Zhoushan, which became China's largest bunkering hub in 2018, with sales of bonded bunkers reaching $3.6 \mathrm{mt}$ in 2018 and 3.2 mt between January and October 2019 (higher y/y by 9 per cent). ${ }^{44}$ The FTZ also holds $22 \mathrm{bcm}$ of storage tanks, of which an estimated $2 \mathrm{bcm}$ is currently available for low-sulphur bunker fuels..$^{45} \mathrm{An}$ additional $3 \mathrm{bcm}$ is under construction. ${ }^{46}$ The majority of the $22 \mathrm{bcm}$ of tank space is reserved for commercial crude storage and the strategic petroleum reserve.

The Zhoushan FTZ is an opportunity for new entrants in a bunker market currently dominated by a handful of state-owned firms, but even in the FTZ, the majors have already taken considerable steps

\footnotetext{
42 Zhoushan port in Zhejiang province, where President Xi Jinping served for five years as Communist party secretary, has already benefited from many central government policies supportive of its nascent bunkering industry.

43 'Zhoushan eyes bunkering hub status', Argus, 26 October 2018.

44 According to the Zhejiang FTZ statistics, http://www.china-zsftz.gov.cn/.

45 'Zhoushan welcomes the opportunity of the marine fuel oil transformation' (Chinese), China Energy News, 12 November

2019, http://www.cnenergynews.cn/csny/csgc/201911/t20191112_757625.html.

46 'The low sulphur era is about to start and the market is in full swing' (Chinese), Anxin futures report.
} 
to become dominant actors. This development is clearly heralding the likely changes in the Chinese bunkering market. Fourteen companies currently have bunkering licences at Zhoushan, with the number growing as Zhoushan builds up its infrastructure and adds licensed companies. Still, PetroChina's bunkering arm, Chimbusco, is by far the largest trader. ${ }^{47}$ Foreign companies are also entering the emerging bunkering hub in Zhoushan: Singapore-based supplier Consort Bunkers became the first wholly owned overseas firm to be awarded a bunker licence in Zhoushan, while Total and trading companies Vitol and Glencore have set up joint ventures to develop bunker fuel operations at the port in anticipation of further liberalization, helped by solid infrastructure and storage facilities there. Reportedly, Total will be able to supply bunkers directly to the Zhoushan market, rather than to the Chinese partner.

Following the success of Zhoushan, several additional FTZs for bonded marine fuels have been authorized in Hainan, Shandong, and Dalian (Liaoning). The Hainan FTZ will also allow qualified companies to supply bonded fuel for vessels on international voyages in the zone, as the government looks to make Hainan a bonded fuel supply hub, dovetailing also with the tighter fuel specifications planned for Hainan in 2022.

\section{LNG bunkering-the next frontier}

For now, refiners (which for the most part belong to China's state-owned oil and gas majors) have been focusing on the bunker fuel market by producing refined products, mainly VLSFO. But as bunker fuel specs continue to tighten and the government increasingly emphasizes LNG in shipping, this is likely to be a focal point for both the majors and China's shippers for the next five years. While use of LNG for bunkering in China's inland waterways was encouraged tentatively from 2013, along with the switch to low-sulphur fuels, the lack of LNG vessels, refuelling, and bunkering infrastructure has limited its growth. LNG in bunkering currently accounts for roughly $1 \mathrm{mt}(1.5 \mathrm{bcm})$ of total domestic bunkering demand, but with more forceful government policies aimed at developing both shipbuilding and refuelling infrastructure by 2025, LNG in shipping is set to grow in the coming years. LNG is starting from a low base and is not therefore expected to have a material impact on gas demand growth. While it may gradually dent demand for diesel on inland waterways, it will increasingly compete with VLSFO.

Use of LNG as a bunkering fuel is consistently mentioned and encouraged in the MoT plans dating from 2013, but the high cost of LNG-fuelled vessels, combined with limited refuelling infrastructure, has limited its uptake. As a result, government policies over time have focused both on developing an LNG shipbuilding industry and on developing LNG bunkering infrastructure. In 2013 the Ministry of Finance issued purchase subsidies for LNG vessels ${ }^{48}$ (Table 2) and sponsored pilot demonstration projects in September 2014 and October 2016.49

Table 2: Subsidies for inland LNG ships, $\$$ millions

\begin{tabular}{lcccc}
$\begin{array}{l}\text { Power (kW) } \\
\text { Construction period }\end{array}$ & $\mathbf{< 0 0}$ & $\mathbf{3 0 0 - 6 0 0}$ & $\mathbf{6 0 0 - 1 , 0 0 0}$ & $>\mathbf{1 , 0 0 0}$ \\
\hline Oct 2013 to Mar 2015 & 12 & 150 & 170 & 200 \\
\hline Apr 2015 to Dec 2015 & 90 & 110 & 130 & 140 \\
\hline Jan 2016 to Dec 2017 & 80 & 95 & 110 & 130 \\
\hline
\end{tabular}

Note: kW = kilowatt.

Source: China Ministry of Finance.

\footnotetext{
47 'China's desulphurization in action' (Chinese), Chineseshipping,

http://info.chineseshipping.com.cn/SEB/SEBWeekly/ALL/201907/t20190709_1323511.shtml

48 'Notice on issuing the measures for the administration of subsidies for ship-class standardization on inland waterways' (Chinese), Ministry of Finance, Ministry of Transport, April 2014, http://www.gov.cn/xinwen/2014-04/17/content_2661069.htm. 49 'Status and prospects of inland waterway LNG application in China' (Chinese), China Shipowners' Association, July 2019, http://www.csoa.cn/doc/15699.jsp.
} 

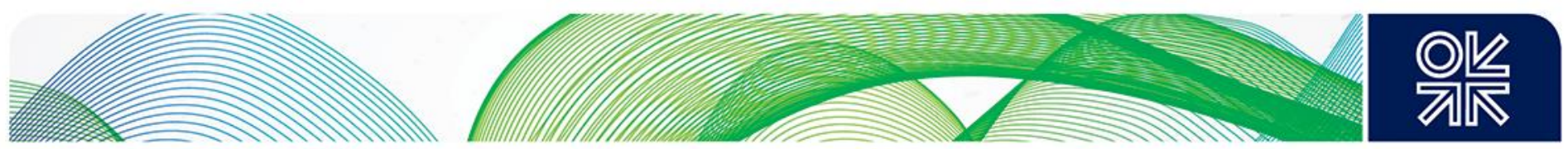

Initially, the focus was on gas injection to substitute up to 70 per cent of the diesel in existing diesel engines, followed by dual-fuel engines and gradually encouraging new builds with pure LNG propulsion. The original subsidies were phased out in late 2017, but LNG ships were subsequently exempt from the Vessel and Vehicle Use Tax, a saving estimate at around CNY 4,500 (\$640) a year. As a result, 99 LNG-fuelled vessels had been built or retrofitted from diesel by the end of 2016. ${ }^{50}$

Efforts to develop LNG bunkering accelerated in August 2018 when the MoT issued a draft timetable for developing LNG bunkering, ${ }^{51}$ aiming to formulate standards and a basic network for LNG use in water transport by 2020, thereby supporting the development of a 'comprehensive and technologically advanced water transport system by 2025'. The plan aims for LNG to account for 15 per cent of new government-owned vessels and 10 percent of all shipping on the largest inland waterways, including the Beijing-Tianjin-Hebei waters and the YRD (with the Yangtze River alone estimated to be the world's most trafficked river, with approximately 100,000 vessels and almost 15,000 new vessels expected to enter operations between 2017 and 2020). Finally, the plan looks to establish two international LNG bunkering hubs. The port of Ningbo-Zhoushan has worked to establish itself as a bunkering hub for low-sulphur marine fuels, both oil-based and LNG. In October 2018, ENN started a 3 Mtpa regas terminal in Zhoushan with bunkering capabilities.

To coincide with the MoT draft, the Ministry of Finance also issued directives granting new tax exemptions for LNG-powered ships and directing local authorities to reduce transit fees and prioritize port access for LNG-powered vessel operators. Much of the construction and retrofitting of LNG fuelled vessels has been undertaken by China Gas Holdings, Kunlun Energy, CNOOC, and a Sinopec subsidiary, China Changjiang bunker. By March 2018 China had 275 LNG-fuelled ships for domestic bunkering of which 160 were new builds and the rest were diesel retrofits;52 113 of them were dualfuel (diesel and LNG). ${ }^{53}$

Most domestic LNG-powered vessels are small and medium-sized with a capacity of less than 30000 cubic metres $\left(\mathrm{m}^{3}\right)$, given the wide variations in channel width and seasonal water levels on China's domestic rivers. For example, the Yangtze River is 18 metres $(\mathrm{m})$ wide at the Chongqing Section, $14 \mathrm{~m}$ in Wuhan and $8 \mathrm{~m}$ in Nanjing, suggesting that shore-based LNG bunkering stations are not appropriate throughout all the inland waterways. ${ }^{54}$ The differences in local conditions also suggest that beyond the national-level framework, incentives to develop LNG bunkering facilities depend heavily on local government incentives.

At the national level, the MoT issued plans to build bunkering terminals along the Yangtze River, with additional guidelines subsequently issued by provincial authorities in Jiangsu, Anhui, Jiangxi, and Guangxi. Other provinces, including Hunan, Hubei, Chongqing, Zhejiang, and Guangdong, are also working on specific layouts for LNG bunkering stations. ${ }^{55}$ Hunan province, for example, expects LNG shipping to displace 38,000 tonnes of diesel in 2020 (out of an estimated 550,000-600,000 tonnes of total diesel demand in the province) and 440,000 tonnes in 2030 , creating $88,000 \mathrm{~m}^{3}$ of gas demand in 2020 (out of an estimated $4 \mathrm{bcm}$ of total gas use in the province) and $250,000 \mathrm{~m}^{3}$ by $2030 .{ }^{56}$

\footnotetext{
50 Fan Hongjun, 'LNG bunkering pontoons on inland waters in China', Natural Gas Industry B, Vol. 5 Issue 2, March 2018 , https://www.sciencedirect.com/science/article/pii/S2352854018300263\#bib1.

51 'Opinions on further promoting the application of LNG use in domestic bunkering' (Chinese), MoT,

http://www.mot.gov.cn/yijianzhengji/zhengjijieguo/201809/t20180918_3088476.html.

52 'Challenges and initiatives for LNG supply security in Asia', IEEJ, October 2018, https://eneken.ieej.or.jp/data/8140.pdf. 53 'Status and prospects of inland waterway LNG application in China' (Chinese), China Shipowners' Association, July 2019, http://www.csoa.cn/doc/15699.jsp.

54 Fan Hongjun, 'LNG bunkering pontoons on inland waters in China', Natural Gas Industry B, Vol. 5, Issue 2, March 2018, https://www.sciencedirect.com/science/article/pii/S2352854018300263\#bib1.

55 Wang Lipeng et al., 'Analysis of difficulties and suggestions for developing ship LNG bunkering stations in China', IOP Conference Series: Earth Environmental Science, 2018.

56 'General layout of LNG refuelling stations in Hunan Province', (Chinese), Hunan Department of Transport, September 2016.
} 
Similarly, Guangdong province estimates new gas demand from LNG shipping to reach $280,000 \mathrm{~m}^{3}$ in 2025 and 710,000 m ${ }^{3}$ in 2035. ${ }^{57}$ Guangdong's gas consumption is estimated to reach $28 \mathrm{bcm}$ in 2020.

In light of the variations along China's inland waterways, the country currently has both shore-based LNG bunkering stations and pontoon bunkering stations (or LNG bunkering barges). In June 2018, China reportedly had 19 LNG bunkering stations along the Yangtze River trunk line (from Shuifu in Yunnan Province to Liuhe Estuary in Jiangsu Province), the Beijing-Hangzhou Canal, the Xijiang shipping trunk line (from Nanning in Guangxi Province to Zhaoging in Guangdong Province) and the YRD water network. Of those, there are seven pontoon bunkering stations along the Yangtze River trunk line and one on the Xijiang shipping trunk line given the large fluctuations in water levels. On the Beijing-Hangzhou Canal, however, and on the YRD water networks, shore-based bunkering stations are more common (totalling 10 in mid-2018). ${ }^{58}$ However, of the 19 bunkering stations, only three are operational given that few vessels stop for refuelling or bunkering. Still, the government aims to build a total of 74 refuelling berths between 2017 and 2025.

Concerted government efforts to support LNG bunkering will help grow the industry, and China's state-owned majors are gradually beefing up investment in infrastructure. In April 2019 CNOOC announced plans to build two LNG refuelling vessels by 2021, with the aim of developing an LNG bunkering network spanning both coastal ports and inland waterways. Two CNOOC subsidiaries will build the vessels: CNOOC Gas and Power, which runs the group's ten LNG terminals, and CNOOC Energy Technology and Service, which is CNOOC's LNG transport unit. The new vessels will refuel LNG for large domestic and international LNG-powered ships around coastal ports, and replenish LNG stocks at inland terminals and refuelling stations. CNOOC had already started to develop its LNG bunkering business in 2018 when it remoulded pipelines at its $3.5 \mathrm{Mtpa}$ Zhuhai LNG import terminal in Guangdong province to make the terminal ready for LNG refuelling operations. The two CNOOC subsidiaries also formed a green shipping alliance with six other gas suppliers along the Yangtze River, including Anhui-based Huainan Mining Industry and Jiangxi Provincial Investment Gas, aiming to promote gas use in Hunan, Hubei, Anhui, and Jiangxi provinces and map out LNG refuelling stations in the area. ${ }^{59}$

Following CNOOC's footsteps, PetroChina's gas unit, Kunlun Gas, signed an agreement with shipbuilder China Ocean in July 2019 to develop LNG infrastructure projects in Jiangxi province. China Ocean owns a shipyard with a shoreline for the construction of LNG storage along China's Yangtze River, while Kunlun Gas can secure gas supplies from its parent company through the WestEast pipeline that runs through Jiangxi province. ${ }^{60}$ Similarly, ENN plans to develop infrastructure at Zhoushan, where its terminal already has three berths capable of receiving bunkering vessels ranging in capacity from $3,000 \mathrm{~m}^{3}$ to $180,000 \mathrm{~m}^{3}$. The terminal is not connected to Zhejiang province's main pipeline system, so ENN plans to offer ship-to-ship refuelling services to domestic and international vessels. ${ }^{61}$

Despite this activity, development is likely to be slow for a number of reasons. First, the costeffectiveness of LNG ships is questionable: their construction costs are still roughly 30 per cent higher than other vessels, and the large variations in domestic LNG prices make it harder to determine returns on investment as well as competitiveness against diesel. ${ }^{62}$ CNPC estimates that LNG bunkering domestically is competitive against diesel when oil prices are at or above $\$ 60-70$ per

\footnotetext{
57 'General layout of inland LNG refuelling stations' (Chinese), Guangdong Department of Transport, 2016.

58 Wang Lipeng et al., 'Analysis of difficulties and suggestions for developing ship LNG bunkering stations in China', IOP Conference Series: Earth Environmental Science, 2018.

59 'CNOOC plans to develop LNG bunkering network', Argus, 23 April 2019.

60 'Kunlun Gas, China Ocean target LNG as a transport fuel', Argus, 25 July 2019

61 'China's ENN eyes LNG bunkering, reloads', Argus, 15 May 2019.

62 'The marine LNG market could become a blue ocean' (Chinese), China Petrochemical News, 1 April 2017,

http://www.cnpc.com.cn/cnpc/rdgzbk/201704/ee28c873be134971ada3a81bdeaacea0.shtml.
} 

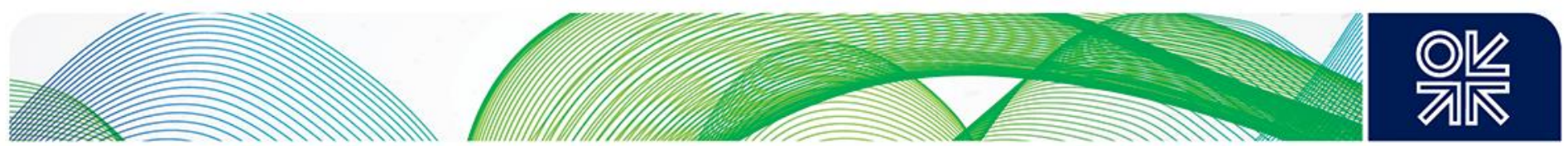

barrel. ${ }^{63}$ Second, LNG is considered a hazardous material in China, leading to additional safety measures at ports and bunkering stations and also placing limitations on the number of ships allowed to navigate at the same time. Third, both construction and operation of LNG bunkering stations are regulated by a number of local departments, including the local branches of the National Development and Reform Commission, housing, port, maritime, water conservancy, fire-fighting, and land administrations. The approval process and co-ordination between departments can be protracted, creating delays due to diverging interests among these departments. Finally, LNG bunkering operations require access to natural gas supplies, which only some provinces will be able to supply at competitive costs.

To be sure, with strong government policies, LNG shipping is likely to increase over the next few years, albeit from a very low base. Domestic LNG bunkering is currently estimated at $1.1 \mathrm{mt}$ (or 1.5 $\mathrm{bcm}$ ), but much like with diesel and fuel oil, official statistics do not break down demand by sector beyond headline figures for transport (Figure 15). Barring a dramatic change in regulation, LNG is unlikely to account for more than $4 \mathrm{bcm}$ before 2025 .

\section{Figure 14: Gas demand by sector, bcm}

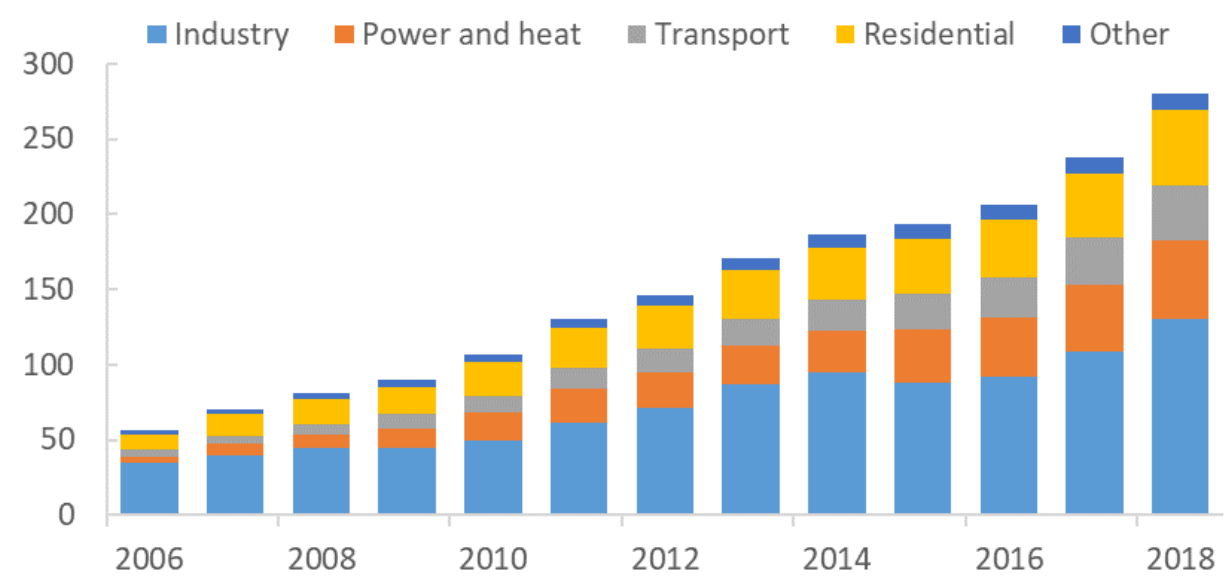

Sources: NBS, CNPC, OIES.

\section{Conclusion}

China has been an early entrant into the clean fuels markets. However, bunkering in China is a relatively small business in comparison to the size of its shipping and refining operations. This is due to the punishing tax treatment of domestically produced refinery-based bunker fuels and a lack of refinery-owned storage for blending operations. LNG bunkering, for its part, is also a nascent business, but it too suffers from a lack of infrastructure, an uncertain regulatory environment, and high costs. For now, LNG shipping accounts for a fraction (under $2 \mathrm{bcm}$ ) of domestic gas demand (which totalled $280 \mathrm{bcm}$ in 2018). With government support measures looking more assertive for 2025 , gas demand from shipping is set to rise, meeting a growing share of inland bunkering demand and further displacing diesel and gradually competing with VLSFO.

In the near-term, China is set to emerge as a growing supplier of VLSFO, with domestic refiners dominating the domestic market (capturing market share away from blenders and imports) and meeting the country's growing requirement for clean fuels. Indeed, Chinese refiners have sufficient complexity and excess capacity to be able to cope with the new IMO 2020 clean fuel requirements. Given the volume of shipping traffic going through Chinese ports, IMO 2020 is an opportunity for 
bunkering operations to expand significantly and for domestic refineries to supply them, once the export tax rebate scheme is introduced.

While the state-owned majors are set to dominate the domestic bunkering market with both residbased supplies in the near term and LNG-based supplies in the medium term, the opening up of FTZs suggests that the blending market will ultimately move to these new zones, generating competition with the refiners there. Given the expected tax changes and investment in infrastructure in anticipation of the change, Chinese refiners are still well positioned to take advantage of the looming IMO 2020 transition and to join the leading players in the bunkering market, not only domestically, but gradually abroad as well. 